\title{
Restoration of Seagrass Meadows in the Mediterranean Sea: A Critical Review of Effectiveness and Ethical Issues
}

\author{
Charles-François Boudouresque ${ }^{1, *}$, Aurélie Blanfuné ${ }^{1}$, Gérard Pergent ${ }^{2}$ (D) and Thierry Thibaut ${ }^{1}$ (D) \\ 1 Aix-Marseille University and University of Toulon, MIO (Mediterranean Institute of Oceanography), CNRS, \\ IRD, Campus of Luminy, 13009 Marseille, France; aurelie.blanfune-thibault@mio.osupytheas.fr (A.B.); \\ thierry.thibaut@mio.osupytheas.fr (T.T.) \\ 2 Università di Corsica Pasquale Paoli, Fédération de Recherche Environnement et Societé, FRES 3041, Corti, \\ 20250 Corsica, France; pergent@univ-corse.fr \\ * Correspondence: charles.boudouresque@mio.osupytheas.fr
}

Citation: Boudouresque, C.-F.;

Blanfuné, A.; Pergent, G.; Thibaut, T. Restoration of Seagrass Meadows in the Mediterranean Sea: A Critical Review of Effectiveness and Ethical Issues. Water 2021, 13, 1034. https:// doi.org/10.3390/w13081034

Academic Editors: Sebastiano Calvo and Agostino Tomasello

Received: 18 January 2021

Accepted: 31 March 2021

Published: 9 April 2021

Publisher's Note: MDPI stays neutral with regard to jurisdictional claims in published maps and institutional affiliations.

Copyright: (C) 2021 by the authors. Licensee MDPI, Basel, Switzerland. This article is an open access article distributed under the terms and conditions of the Creative Commons Attribution (CC BY) license (https:/ / creativecommons.org/licenses/by/ $4.0 /)$.

\begin{abstract}
Some species of seagrasses (e.g., Zostera marina and Posidonia oceanica) have declined in the Mediterranean, at least locally. Others are progressing, helped by sea warming, such as Cymodocea nodosa and the non-native Halophila stipulacea. The decline of one seagrass can favor another seagrass. All in all, the decline of seagrasses could be less extensive and less general than claimed by some authors. Natural recolonization (cuttings and seedlings) has been more rapid and more widespread than was thought in the 20th century; however, it is sometimes insufficient, which justifies transplanting operations. Many techniques have been proposed to restore Mediterranean seagrass meadows. However, setting aside the short-term failure or half-success of experimental operations, long-term monitoring has usually been lacking, suggesting that possible failures were considered not worthy of a scientific paper. Many transplanting operations (e.g., P. oceanica) have been carried out at sites where the species had never previously been present. Replacing the natural ecosystem (e.g., sandy bottoms, sublittoral reefs) with P. oceanica is obviously inappropriate in most cases. This presupposes ignorance of the fact that the diversity of ecosystems is one of the bases of the biodiversity concept. In order to prevent the possibility of seagrass transplanting from being misused as a pretext for further destruction, a guide for the proper conduct of transplanting is proposed.
\end{abstract}

Keywords: Cymodocea nodosa; ecosystem diversity; Mediterranean; natural recolonization; Posidonia oceanica; seagrass decline; seagrass restoration; transplanting; Zostera marina

\section{Introduction}

Seagrasses are part of the Magnoliophyta (flowering plants), which number more than 295,000 species [1]. The vast majority of these species are terrestrial, while freshwater taxa represent $\approx 2450$ species [2] and seagrasses only represent 67 species, including Ruppia maritima $[3,4]$.

Despite their small number, seagrasses play a role of paramount importance in coastal habitats worldwide. They provide ecological goods and ecosystem services that contribute to human welfare, e.g., habitat for a wide diversity of species, nursery, enhanced fisheries, nutrient cycling, carbon sequestration, production of sand (the "sand factory"), beach, and shoreline protection [5-10]. In the Mediterranean Sea, seven species of seagrasses occur [11,12]. Posidonia oceanica is the only one that is endemic to the Mediterranean [13]. Cymodocea nodosa, Zostera marina and Z. noltei, native to the Mediterranean, have a broader temperate distribution. Ruppia maritima (synonym R. cirrhosa) is almost entirely restricted to brackish lagoons and salt marshes [14]. Finally, Halophila stipulacea and H. decipiens are introduced species, via the Suez Canal and ballast water, respectively [15-17].

The severe worldwide decline of the seagrass meadows is a classic refrain in the literature (e.g., [18-25]). The most spectacular and best documented decline is that of Z. marina, known as the "wasting disease", which occurred in the 1930s; its cause remains 
controversial: a stramenopile parasite or a climatic episode [26-30]. Since then, other decline events of $Z$. marina, conspicuous but more localized than the wasting disease, have been reported in Chesapeake Bay (USA), Portugal, Arcachon Bay (France), Netherlands, Japan, California (USA), etc.; they have been attributed to local disturbances, e.g., pollution, turbidity, and oyster dredges [28,31-37]. Some were also due to natural events, such as the passage of the tropical storm Agnes in 1972 in Chesapeake Bay [31].

There can be no doubt that seagrass meadows have declined worldwide, in particular Z. marina meadows. However, it is legitimate to wonder whether the overall decline of seagrasses has not been exaggerated by certain authors, as evidenced in the case of the Mediterranean Sea [11,24,38-40]. As Boero [41] and Duarte et al. [42] suggested, it is easier to publish in high IF (Impact Factor) journals if you announce the apocalypse than if you describe moderate changes. Very few articles describe the recent (2000s) reversal of decline for European seagrass meadows [24].

Thousands of cases of the decline of seagrass meadows have been reported in the global ocean, and they are completely credible. It should just be noted that cases of subsequent recolonization, as well as cases where a seagrass is expanding at the expense of a declining species [11], are more rarely published. Therefore, adding together the episodes of decline without taking into account the cases of recolonization or substitution can constitute a bias. Extrapolation of the cases of decline to the entire seagrass distribution area constitutes another bias: the "undocumented" areas may correspond to areas where nothing is happening, and regarding which it is therefore difficult to publish in high IF journals. Such extrapolations would result in an overestimation of global seagrass decline. Finally, although the authors indicate clearly, in general, whether they are referring to the percentage of surface area lost (or gained) by a species, or of the percentage of sites where the species is in decline, without change or in progression (trajectories), the authors who quote them sometimes confuse the two; however, a 33\% decrease in surface area is not synonymous with $33 \%$ of the sites where a decline has been observed.

Waycott et al. [19] stressed the acceleration of seagrass declined from $1 \%$ per year before 1940,1-7\% per year between 1940 and 1990, to 7\% per year since 1990. Although the authors clearly warned that these estimates were based on data available at the time, from a limited number of regions of the world ocean, and reported the geographical and historical bias in their dataset, some later authors cited this article without reference to these caveats. Yet a very simple mathematical model indicates that these estimates cannot be extended to the world ocean: there would be hardly any seagrass meadows left in the world today, which is clearly not the case [11,43].

Therefore, the debate on the reality or the extent of the decline of seagrasses is important, insofar as this decline is at the basis of attempts to restore seagrass meadows.

Here, we have considered the case of the Mediterranean, which is of particular interest because a considerable corpus of data is available on the decline, the non-decline, or the recolonization of seagrasses, and we have examined the justification for and effectiveness of seagrass restoration operations. Furthermore, the Mediterranean is often regarded as representative of the world ocean in miniature [44].

\section{Are Seagrasses on the Decline in the Mediterranean Sea?}

First of all, it is important to clarify that the general perspective (a combination taking all seagrasses together) may be different from the specific perspective (a particular species). One species can be in decline while another is progressing at its expense. Adding together all the episodes of decline, without considering subsequent recolonization as well as the progression of other species, can therefore lead to a biased view of the general situation [11].

Mapping a seagrass meadow, and comparison with previous maps, can provide a reliable basis for inferring changes over time [11,39]. However, differences between maps might be due to errors in the ancient maps and/or the improvement of mapping methods rather than to changes over time, as emphasized by Leriche et al. [45], Astruch et al. [46], Pergent-Martini et al. [47], and Valette-Sansevin et al. [48]. For example, in Corsica, the 
surface area of Posidonia oceanica beds was estimated at $624 \mathrm{~km}^{2}$ [49], then at $537 \mathrm{~km}^{2}[47,48]$, which obviously is not due to a decline, but to an improvement in the accuracy of the mapping. In the same way, in Provence and the French Riviera, the surface area of $P$. oceanica was estimated at $255 \mathrm{~km}^{2}$ [50] and subsequently at $265 \mathrm{~km}^{2}$ [51]; in the Port-Cros Archipelago (Provence), estimates of the surface area of P. oceanica increased from 345 ha in the 1980s [52] to 418 ha in the 2000s [53] and to 439 ha in the 2010s [46]; again, it is prudent to attribute these increases to improved mapping methods.

\subsection{Posidonia Oceanica}

A variety of natural processes can generate dead matte of $P$. oceanica, i.e., areas where the $P$. oceanica shoots have died, but where the dead rhizomes may persist for millennia since their decay is very slow $[6,54,55]$.

(i) The increase in the thickness of the matte, in shallow areas, can bring the meadow too close to the sea surface; there, the shoots encounter conditions that are no longer compatible with their survival, giving way to a dead matte of natural origin; this is the case in the Bay of Giens (Provence, France) [50].

(ii) A P. oceanica ramet (i.e., a set of shoots interconnected by live rhizomes) allows photosynthates and nutrients from a shoot to be exported toward rhizomes and then allocated to the other shoots of the ramet [56]. For a given shoot, this constitutes a kind of insurance: should its budget go into deficit (e.g., due to the covering of leaves with epibiota, overgrazing, self-shading, etc.), its needs will be supplied by neighboring shoots. However, when an orthotropic (i.e., vertical) rhizome exceeds a certain length, this process becomes inefficient, making the survival of the shoot precarious [57]. Hence, small patches of dead matte in a healthy P. oceanica meadow may result simply from the death of such vulnerable shoots rather than from a disturbance; these structures, of natural origin, have been termed "autogenic dead matte patches" (Figure 1) [11].

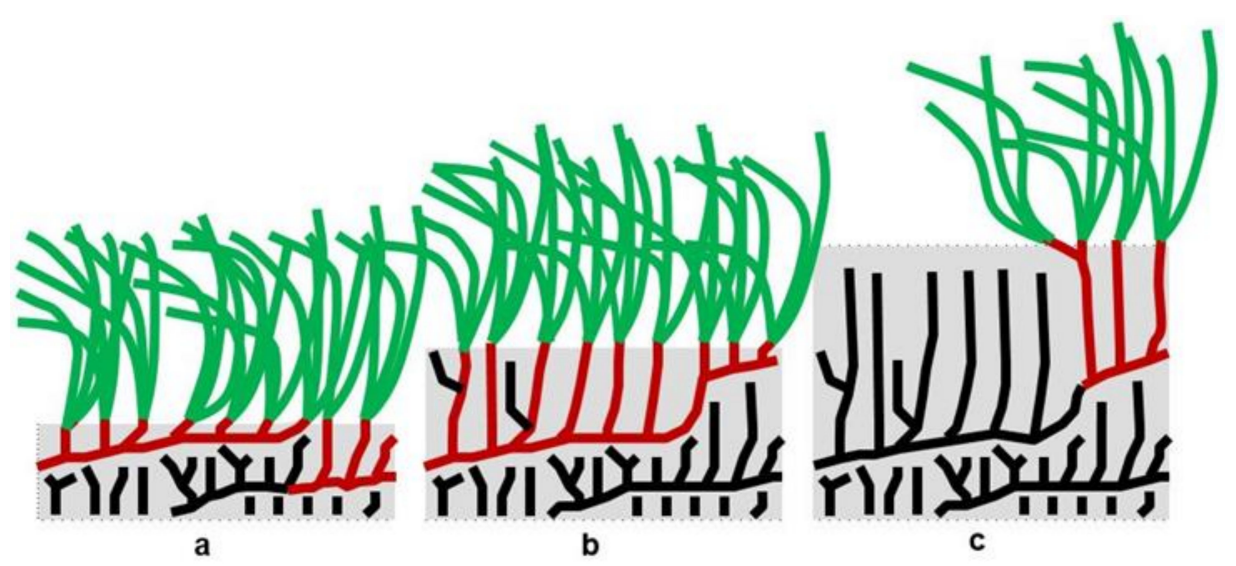

Figure 1. Formation of an autogenic dead matte patch within a Posidonia oceanica meadow. Orthotropic (vertical) rhizomes react to the trapping of sediment and their burial by vertical growth so that the sea bottom rises $(\mathbf{a}-\mathbf{c})$. Leaf shoots located at the tips of orthotropic rhizomes, that are too long, will die, which results in the formation of a patch of dead matte of natural origin. On the right side of (c), a new plagiotropic (horizontal) rhizome is starting to recolonize the dead matte patch. Green: leaves; red: live rhizomes; black: dead rhizomes. From Boudouresque et al. [11], adapted.

(iii) In plain type meadows (see $[55,58]$ ), areas of dead matte and sand intermattes (breaks within the meadow, filled with sand) can be of natural origin. In addition, shifting intermattes are furrows several dozen metres long and several metres wide, lying parallel to the shore; the side of the shifting intermatte that is closest to the shore is made up of an erosion scarp, which is actively eroded; the central part of the shifting intermatte is made up of dead matte; the side that is furthest away from the shore is made up of a meadow front with plagiotropic (horizontal) rhizomes that tends to recolonize the intermatte. Over time, the shifting intermatte moves along in a parallel direction toward the shoreline 
(Figures 2 and 3). Typical shifting intermattes have been observed in Calvi Bay and off Aleria (Corsica), in the bays of Giens and Hyères (Provence, France), and in southern Latium (Italy) [50,55,59-63].
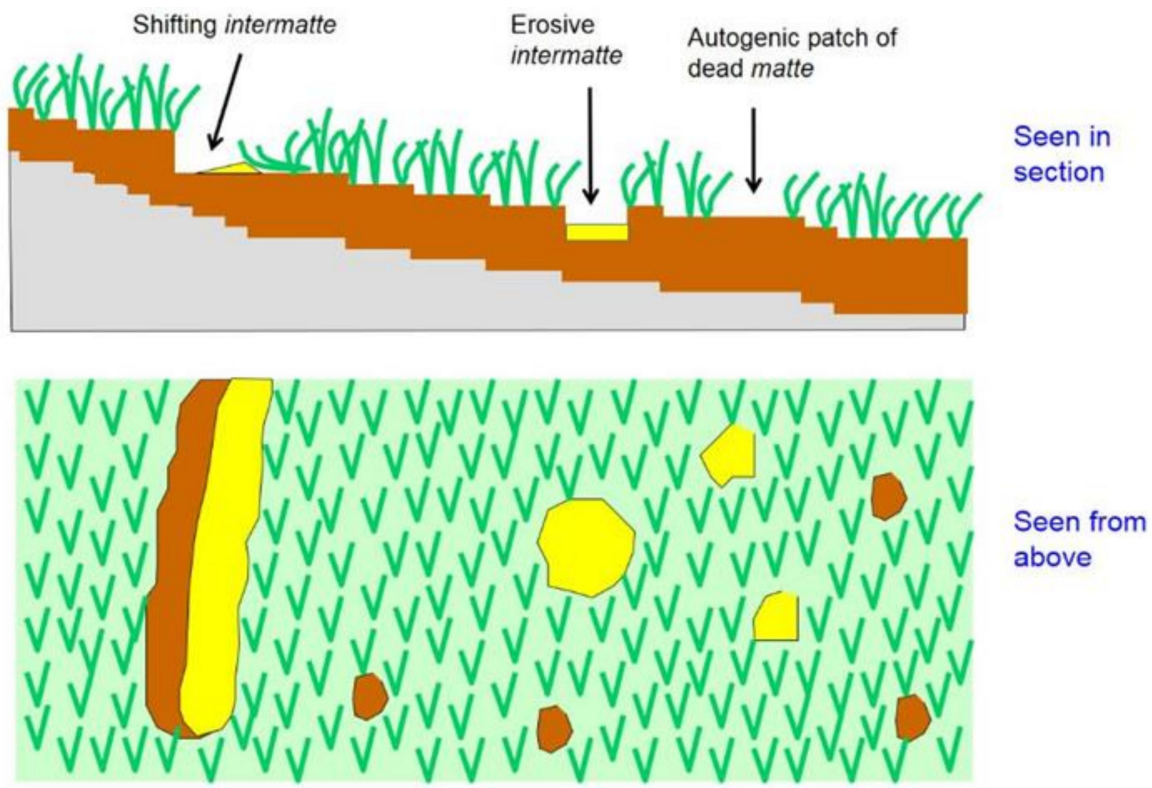

Figure 2. Areas of dead matte of natural origin in a plain type meadow of Posidonia oceanica. The shoreline is to the left. From Boudouresque et al. [55], adapted.

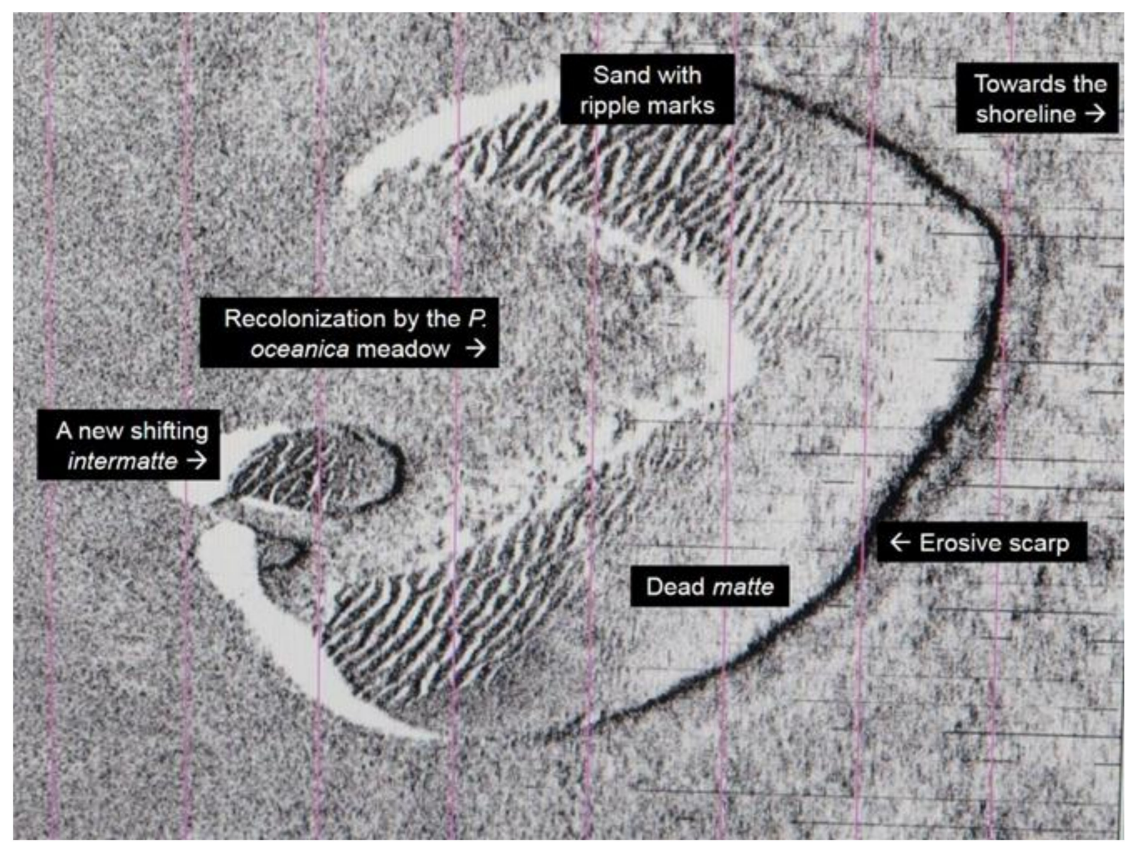

Figure 3. Shifting intermattes. $30 \mathrm{~m}$ depth. U Caterraghju (Aleria, eastern coast of Corsica). Sidescan sonar image. Mission Coralcorse (Gérard Pergent and Ifremer). Photo ( $)$ Charles-François Boudouresque.

(iv) Dead matte of natural origin also occurs in the hill type meadow $[55,58]$. In the striped meadows, which occur in shallow areas in Corsica (Portivechju), Sardinia and are widespread in Tunisia and Libya, 1-2 m-wide and several dozen metres long strips of P. oceanica are separated by extensive areas of dead matte occupied by a Cymodocea nodosa and/or Caulerpa prolifera meadow; each P. oceanica strip shifts, parallel to itself, against the dominant current, at an average speed of $10 \mathrm{~cm}$ per year (Figure 4 ). A cross-section of a 
strip shows on one side a front of plagiotropic (horizontal) rhizomes that progress onto the dead matte, a gentle slope behind the front, and a small erosive scarp where the strip disintegrates (Figure 5) [55,64,65].

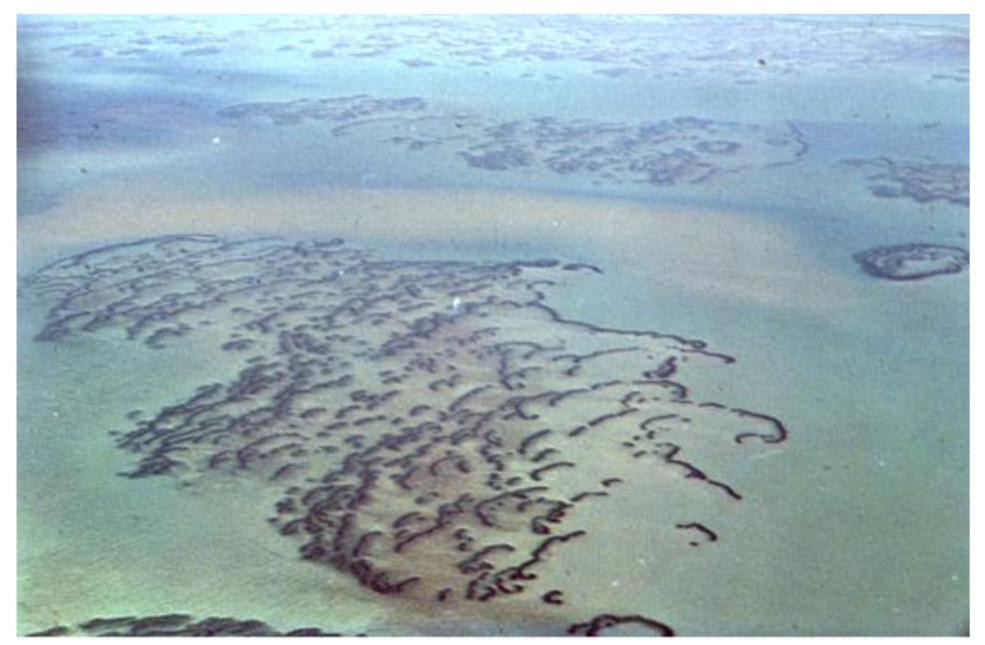

Figure 4. A striped meadow of Posidonia oceanica. Kerkennah Islands, Tunisia. From Blanpied in [55].

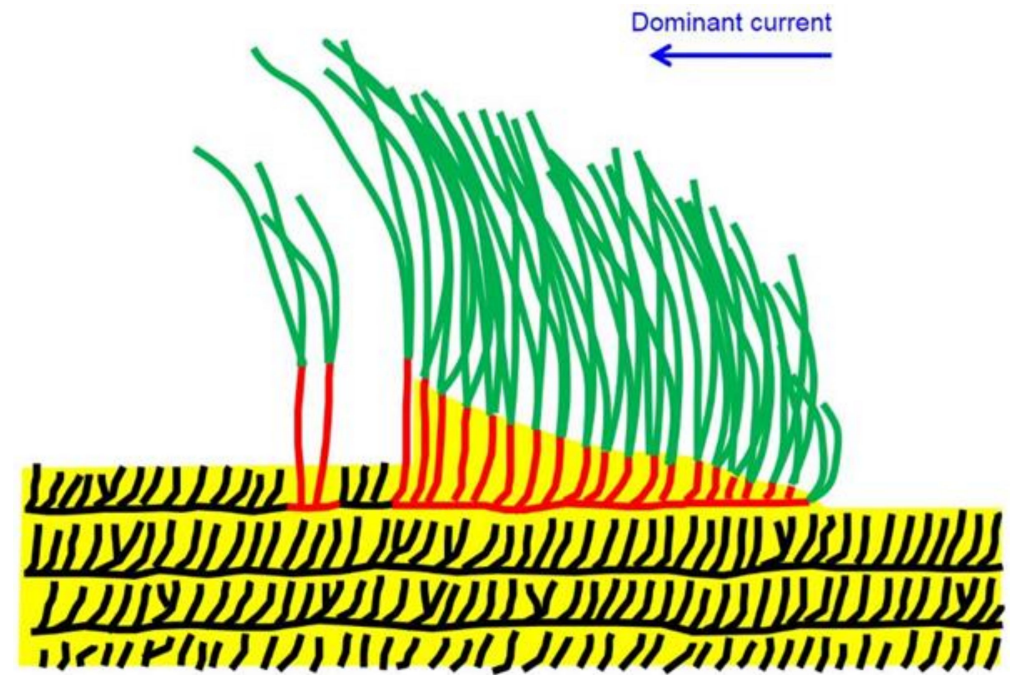

Figure 5. A cross-section within a strip of striped meadow. The progression is made toward the right by a plagiotropic (horizontal) rhizome, whereas the strip is eroded on the left by the hydrodynamism (generated by the dominant current). Black: dead rhizomes; red: live rhizomes; green: leaves; yellow: sediment.

(v) In many areas, an extensive belt of dead matte occurs beyond the lower limit of the $P$. oceanica meadow. This has been considered as a consequence of modern pollution and water turbidity. In the Gulf of Marseille (Provence, France), this belt occurs between 22 and $30 \mathrm{~m}$ depth; however, ${ }^{14} \mathrm{C}$ dates these dead mattes from 573-885 CE [66]. The same phenomenon occurs in the Bay of Hyères [67]. If we consider a longer time scale, at the time of the Last Glacial Maximum (LGM), about 18,000-20,000 years ago, the sea level was $120-140 \mathrm{~m}$ below that of today [68-70]. From that time to the present, the sea level has risen continually [71,72] Any rise in sea level resulted in a withdrawal of the lower limit of the P. oceanica meadow. Where sediment deposition is weak, the resulting belt of dead matte may give rise to misinterpretation, for instance as a case of decline due to human impact (Figure 6) [11,67]. 
20,000 years ago

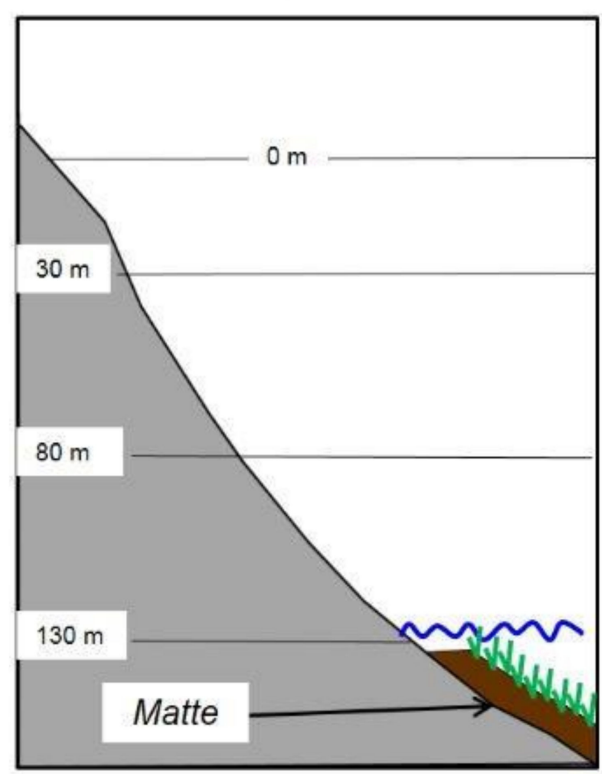

9000 years ago

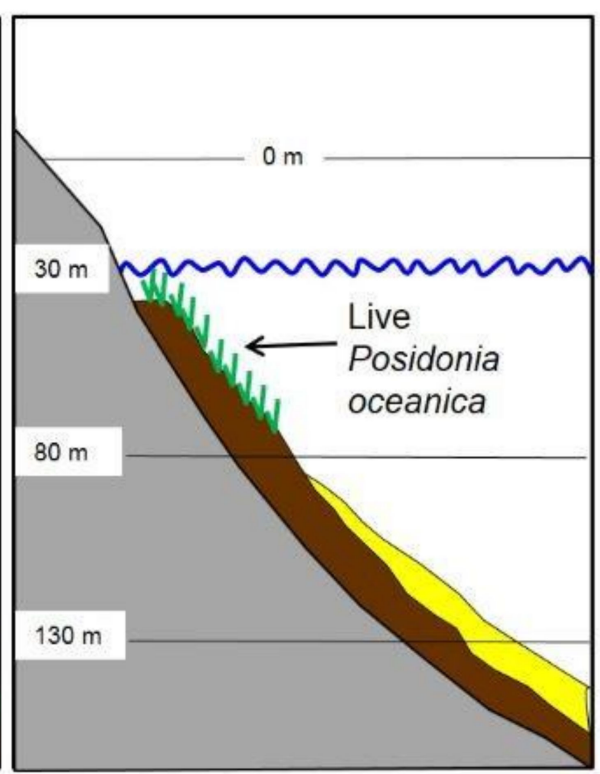

Today

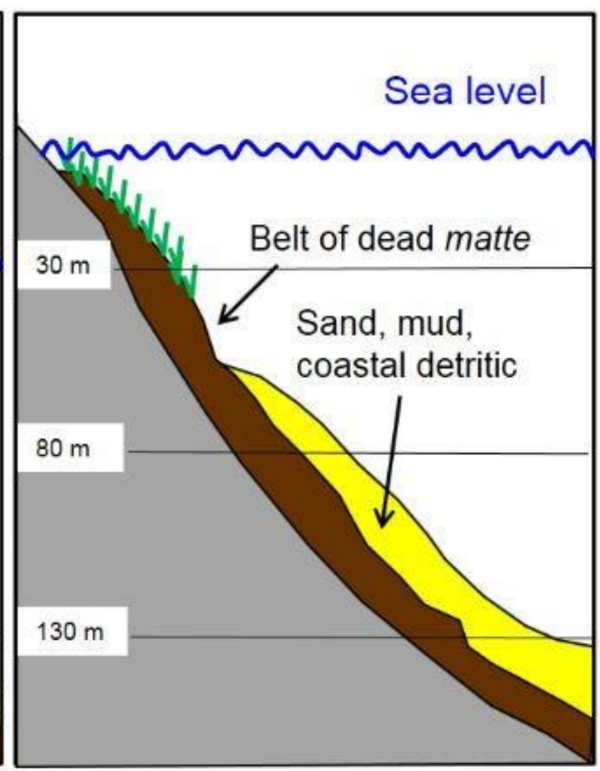

Figure 6. The post-LGM (Last Glacial Maximum) rise in sea level. Posidonia oceanica meadows have spread upwards, following the rise in sea level, leaving behind a belt of dead matte of natural origin. This belt could be confused with modern withdrawal.

The fact that dead matte of P. oceanica may be of natural origin is often underestimated by authors, which may lead to an overestimation of the withdrawal. The paradigm example is that of the Bay of Giens (Provence); Blanc and Jeudy de Grissac [73] reported in the 1970s a 40-m per year withdrawal of the meadow, on the basis of snorkelling near the shore, above a natural dead matte, without any means of geographical positioning; subsequently, accurate mapping of the Bay of Giens (side-scan sonar, with ground truths) revealed that this meadow was in an excellent state of health, perhaps the best along the whole of the French mainland coast $[11,50]$. However, certain authors of scientific articles still refer to Blanc and Jeudy de Grissac [73]. Another example is that of the whole Provence and French Riviera region (one of the most human-impacted regions in the Mediterranean); according to Deter et al. [74], Andromede oceanologie [51], and Holon et al. [75], over one century (since $1922 \mathrm{CE}$ ), between the sea surface and $15 \mathrm{~m}$ depth, $86 \%$ of the P. oceanica meadow remained unchanged, $13 \%$ regressed, and $1 \%$ progressed. These figures are relatively moderate and do not validate the claims of certain authors.

In any case, there is no doubt that $P$. oceanica has strongly declined around the major Mediterranean ports (Barcelona, Marseille, Genoa, Naples, etc.), and on a large scale in Liguria (Italy), where the loss could be over 30\% [76-79]. However, the estimates of Marbà et al. [80] indicating that between $13 \%$ and $50 \%$ of the overall area of P. oceanica was lost during the last 50 years, and that the loss was about $6.9 \%$ per year, obviously concern local areas, not the whole Mediterranean, as stressed by the authors.

\subsection{Zostera Marina}

In the northern part of the Mediterranean Sea (western Mediterranean, Adriatic and Aegean seas), the decline of Zostera marina meadows has been related to human activities: pollution, turbidity, freshwater inputs, anoxy.

Until the 20th century, Berre Lagoon (southern France) harboured a $60-\mathrm{km}^{2}$ meadow of Z. marina, which is perhaps the largest in the Mediterranean [81]; during the 20th century, Z. noltei progressively replaced Z. marina $[81,82]$. Since 1966 , the diversion of the Durance River toward the lagoon resulted in the extinction of both Zostera species and their replacement by the freshwater species Stuckenia pectinata (synonym Potamogeton pectinatus). 
The reasons for the failure of Zostera spp. to recover, despite a drastic reduction in pollution and freshwater and silt inputs, remain unclear [81].

Similar declines of Z. marina have been documented elsewhere in the Mediterranean. In Venice (Italy) and Thau (Occitania) lagoons, episodes of decline have been followed by more or less rapid natural recolonization [83,84], with the exception of the northernmost part of Venice Lagoon [85]. At Toulon (Provence), a small stand, in a sheltered bay subject to several human disturbances (coastal development, mooring, aquaculture and urban waste), has totally disappeared since the 1970s [11]. In Ghar el Melh Lagoon (northern Tunisia), the extirpation of Z. marina can be related to the restriction of water exchange with the open sea, salinity increase, pollution and silting [86]. In the Alboran Sea, from Málaga to Almeria (Spain), Z. marina has undergone a strong decline from 2005, to the point of becoming extinct in most coastal areas where it used to form extensive meadows [33].

In spite of local losses (e.g., Berre Lagoon, Toulon; see [87]), and in contrast with the Atlantic and Pacific coasts [29], no general regression of Z. marina has occurred in the Mediterranean. On the contrary, extensive meadows are still thriving, despite conspicuous human impact, in many localities, e.g., Venice Lagoon, Thau Lagoon, the Gulf of Fos (west to Marseille, France), Bizerte Lagoon (Tunisia), Els Alfacs Bay (Ebro delta, Spanish Catalonia), Alboran Sea, Marmara Sea, etc. [83,88-90]. This is surprising, insofar as the warming of the waters should make this species of cold affinities decline throughout the Mediterranean, which, at least for the moment, is not the case, whereas in the Atlantic, for instance, Z. marina is classified as the most endangered seagrass in Portugal [36,91].

\subsection{Zostera Noltei}

At sites with fluctuating salinity and turbidity, e.g., in Camargue (SE France), the extension of Z. noltei presents consistent patterns of change over the years [92,93]. In Berre Lagoon (Provence), the disappearance of extensive Z. noltei meadows and their replacement by the freshwater species $S$. pectinata can be related to the diversion of the Durance River toward the lagoon, the decrease in salinity, and the increase in turbidity [81].

As in the example of Berre Lagoon, Z. noltei meadows in Canet Lagoon (Occitania) were replaced in the early 1950s, after an exceptional spate of the tributary river, by S. pectinata [94,95]. In Ghar El Melh Lagoon (N Tunisia), Z. noltei and Z. marina were replaced by an extensive Ruppia maritima meadow after the reduction of seawater exchanges with the open sea [86]. In Venice Lagoon, the dramatic loss of Z. noltei (1990-2002) can be ascribed to the spectacular recovery of $Z$. marina $[84,96]$. In the Port-Cros Archipelago MPA, in the lagoon located behind a Posidonia oceanica barrier reef, Z. noltei disappeared in the 1990s [97].

However, the decline of Z. noltei does not constitute a universal feature. Zostera noltei frequently derives benefit from the decline of other seagrasses and the introduction of restoration plans. In the heavily populated and industrialized Gulf of Thermaikos (Greece), P. oceanica and C. nodosa losses were followed by the conspicuous expansion of $Z$. noltei [98]. In the Tunis northern Lagoon (Tunisia), after the virtual collapse of Z. noltei due to a dramatic increase in pollution (1920s through 1980s), an ambitious plan for sewage treatment, improvement of water exchange with the open sea, and establishment of a counter-clockwise water circulation system led to the recovery of mixed meadows of Z. noltei, R. maritima, and C. nodosa [99].

\subsection{Cymodocea Nodosa}

Cymodocea nodosa meadows are subject to wide natural fluctuations. Meadows rapidly spread during warm episodes and shrink during cold years. They also rapidly respond to human-induced environmental changes. In Mar Menor Lagoon (Spain), increased water exchanges with the open sea have led to a decrease in salinity and the expansion of the green alga C. prolifera at the expense of C. nodosa [100,101]. In Ghar El Melh Lagoon (Tunisia), a reduction in the number of channels between the lagoon and the open sea induced the replacement of C. nodosa by Z. noltei and Z. marina in the early 1980s, before they were 
replaced by an extensive $R$. maritima meadow $[11,86]$. The 44-ha Le Brusc Lagoon (eastern Provence) was almost entirely colonized by $C$. nodosa in the mid-20th century $[54,102]$; this meadow $(\approx 30$ ha) was still present five decades later $[103,104]$. Subsequently, it declined to 17 ha in 2008 [105] and almost collapsed in 2011 [106,107], possibly as a result of overgrazing by the teleost Sarpa salpa.

Overall, C. nodosa meadows are expanding, firstly because the species is favored by the sea water warming, and secondly, because it benefits from the decline of the P. oceanica meadows $[11,90]$. This is particularly the case in Liguria (Italy), with an ecosystem regime shift, the dead matte of $P$. oceanica being colonized by $C$. nodosa and the non-indigenous green macroalga Caulerpa cylindracea, which is an alternative state that seems unlikely to be reversible [108-110].

\subsection{Ruppia Maritima}

Ruppia maritima (including R. cirrhosa, now considered as a heterotypic synonym; but see [111]) is usually restricted to brackish lagoons. There, a highly variable environment induces wide fluctuations in the surface area of the R. maritima meadows. Salse-Leucate Lagoon (Occitania, France), Ichkeul Lagoon and Ghar El Melh Lagoon (northern Tunisia) illustrate the abrupt fluctuations of this species.

Some populations of R. maritima have been totally lost, such as an $8-\mathrm{km}^{2}$ mixed $R$. maritima and S. pectinata meadow in Bolmon Lagoon (Provence), due to hypereutrophication and restriction of seawater exchanges [112,113]. In contrast, following the 1988 restoration plan for the Tunis northern Lagoon, the recovery of R. maritima has been spectacular: locally extinct in the 1970s, it is now the dominant species of this lagoon, with a $17-20 \mathrm{~km}^{2}$ surface area [99].

\subsection{Halophila Stipulacea}

Halophila stipulacea is native to the Red Sea. It probably entered the Mediterranean Sea via the Suez Canal a few years after its inauguration (1869 CE), since it was observed at Rhodes in 1894 [15]. Since then, it has slowly but steadily spread northwards and westwards, reaching Sicily, southern mainland Italy, Tunisia, Albania, and the northern Aegean Sea; its spread is obviously enhanced by sea water warming and by pleasure boat anchoring [17,90,114-117]. From the Mediterranean, functioning as a hub, it reached the Caribbean Sea, where its expansion has been extraordinarily rapid [17].

Once installed at a new station, $H$. stipulacea stays there and often progresses. The only case of local extinction was in the harbor at Palinuro, $130 \mathrm{~km}$ south of Naples (mainland Italy): first sighted in 2006, the species was no longer detectable after 2011 and was considered extinct in the area; in 2017, the species was recorded again in the area, possibly as the result of a new colonization event $[115,118]$.

\subsection{All Seagrasses}

There is no doubt that some seagrass species have dramatically declined in the Mediterranean. In Berre Lagoon (Provence, France), large Z. marina meadows totally disappeared in the late 20th century [81,82]. In Liguria (Italy), the decline of P. oceanica is cause for concern $[77,79,119]$. In the region of Alicante (Spain), the decline of $P$. oceanica is also conspicuous [76].

The main causes of decline of P. oceanica are land reclamation for coastal development, such as in the French Riviera and Monaco, the construction of harbors such as at Marseille (Provence) and Piombino (Liguria), the anchoring of cruise ships such as at Villefranche-sur-Mer (French Riviera), and trawling, such as in Corsica and the Alicante region (Spain) [11,55,76,90,120-124].

The replacement of one seagrass by another, namely P. oceanica by C. nodosa, cannot be considered as a neutral balance, as the total surface area of the seagrasses remains unchanged; the former species is a "constructional" species, while the latter is a "non- 
constructional" one, which results in a conspicuous alteration in ecosystem structure and functioning $[11,110]$.

Interestingly, all the native Mediterranean seagrasses (C. nodosa, P. oceanica, R. maritima, Z. marina, and Z. noltei) are considered as LC (Least Concern) in the IUCN red list.

\section{Concerning Natural Recolonization}

Assessment of natural recolonization after a disturbance is essential when considering seagrass restoration operations, as stressed by Cunha et al. [125]. The slow growth of Posidonia oceanica is a well-known feature: $1-7 \mathrm{~cm}$ per year for orthotropic rhizomes and less than $14 \mathrm{~cm}$ per year for plagiotropic rhizomes [55,126-132]. The mean growth of plagiotropic rhizomes, over a period of several decades, was $2-4 \mathrm{~cm}$ per year $[121,133,134]$. The idea that natural recolonization by $P$. oceanica is very slow is mainly based on observations dating from the peak of pollution and coastal development; these human impacts hampered recolonization. Today, the perception would undoubtedly be different.

Natural recolonization can take place in three ways: (i) the progression of a meadow margin owing to plagiotropic rhizomes, (ii) the export of cuttings through to the currents, in particular during storms, and (iii) seed germination.

For a long time, cuttings were considered the main, if not almost the only, way of dispersal of $P$. oceanica (e.g., $[54,55,127,135])$. The relative scarcity of flowering sightings [136-142], perhaps due to the fact that flowering occurs in the fall, a season when divers are also scarce, may explain the underestimation of dispersal by seeds. The arrival of lepidochronological analysis, which allowed the exploration of past flowering within the matte, showed that flowering events were not so uncommon [139,141,143-145]. In addition, the fact that $P$. oceanica flowers and produces seeds only at intervals of several years has sometimes been interpreted as a mismatch with regard to the environmental conditions of the Mediterranean or a weakness explaining its modern decline. (i) To refer to a mismatch with the Mediterranean environment (e.g., [54,146,147]), for a species that has been present there for millions of years, which has gone through the Messinian salinity crisis and around thirty glacial and interglacial episodes, and which is today the most widespread macrophyte in the Mediterranean, is barely credible. (ii) For a long-lived species, K strategist, fruiting every year is not an optimal strategy; fruit predators adapt their number to a predictable resource, so that all seeds are consumed. The flowers and fruits of $P$. oceanica are much appreciated by herbivores, such as the fish Sarpa salpa and the sea urchin Paracentrotus lividus [148-151]. The predator saturation strategy consists in synchronized heavy seed production at unpredictable time intervals so that herbivores are unable to consume all the seeds, allowing a large amount of seeds to escape consumption and germ [152-154]. Therefore, the irregularity of flowering and fruiting is not a weakness but rather a strength for $P$. oceanica. All in all, there is growing evidence that seedling recruitment plays a major role in the process of recolonization after disturbance [43].

Meinesz and Lefèvre [133] provided a good example of the slowness of recovery. In 1943, during World War II, in the Bay of Villefranche-sur-Mer (French Riviera), a bomb missed a ship at anchor and destroyed the P. oceanica meadow over a circular area with a radius of $85 \mathrm{~m}$, between 6 and $15 \mathrm{~m}$ depth. Forty years later, only one-third of the destroyed meadow has been recolonized. Patches of $P$. oceanica progressed at an average speed of $4 \mathrm{~cm} /$ year; new patches (from seeds or cuttings) appeared at a rate of $3 /$ ha/year. A similar example is that of the Plateau des Chèvres bomb (Marseille, Provence), in 1942; the initial surface area of the crater was 1.13 ha; total recovery is expected to have occurred by 2030, i.e., after 90 years [155-157]. At Bergeggi (Liguria, Italy), following a dramatic decline of P. oceanica, there are signs of slow recovery of the upper limit of the meadow, which is progressing shoreward; P. oceanica also increases at the expense of sand patches [110]. At depth (14 to $28 \mathrm{~m}$; region of Alicante, Spain), in an area severely affected by illegal trawling, the natural recovery was studied after the installation of anti-trawling artificial reefs; the extrapolated time of total recovery could be almost 100 years [130]. 
Unexpectedly, natural recolonization by marginal growth can be relatively rapid, when the causes of the decline have ceased to act, for example after the setting up of a sewage treatment plant, at Marseille (Figure 7) and in the Bay of Giens (Provence) [158]. In the Bay of Giens, in a permanent quadrat of $36 \mathrm{~m}^{2}$, located $60 \mathrm{~m}$ from the outlet of the discharge from the sewage treatment plant, the P. oceanica cover increased from $19 \%$ in 1987 to $52 \%$ in 2000, which represents a remarkable rate of progression [159]. In the Marine Protected Area (MPA) of Egadi Islands (off Sicily, Italy), patches of P. oceanica, up to 1-m in diameter, have begun to colonize a metallic 40-m long wreck, at $15 \mathrm{~m}$ depth [160].

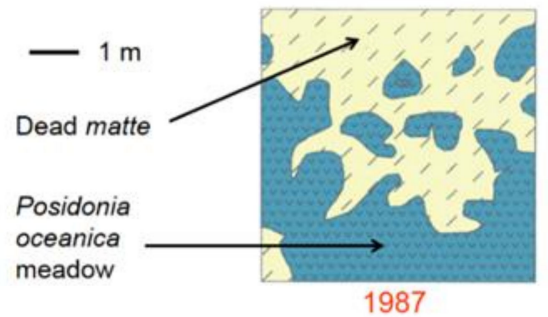

1987

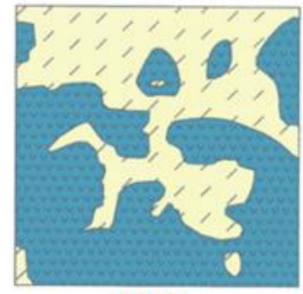

1989

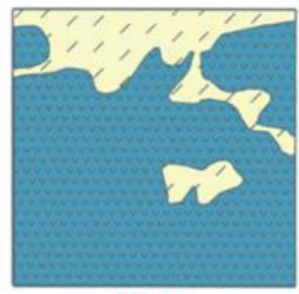

1993
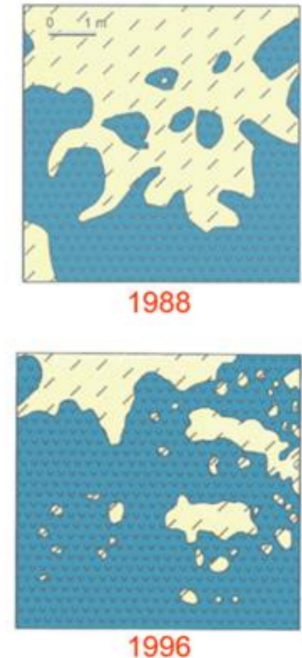

1996

Figure 7. A permanent quadrat $(5 \mathrm{~m} \times 5 \mathrm{~m})$ in Prado Bay, Marseille (France). The sewage water treatment plant was put in operation in 1987. From Gravez et al. [158], adapted.

Off the harbor at Ischia (Gulf of Naples), a 300-m trench was dredged in a P. oceanica meadow to set up a gas pipeline; then, it was filled with rubble after the deployment of the pipeline in 2009. Ten years later, 121 patches of $P$. oceanica had spontaneously colonized the rubble substrate, probably from cuttings coming from the surrounding meadow; these patches cover an area of $334 \mathrm{~m}^{2}$, corresponding to $12 \%$ of the surface area of the trench (Figure 8) [161]. In a same way, in Sicily, a gas pipeline trench, crossing a P. oceanica meadow between the shore and $20 \mathrm{~m}$ depth, was in part backfilled using calcareous rubble; 8 to 10 years later, the rubble became naturally and partially recolonized by P. oceanica $[135,162-164]$.

Sightings of seedlings and of young plants grown from seeds are more common than previously thought, either because of an increase in flowering events, perhaps linked to warming, or because of a greater interest of scientific divers in such observations. Seedlings, at least one year old, were observed on hard substrates at 0.5 to $2 \mathrm{~m}$ depth in the Egadi Archipelago (Sicily) [165]. Other sightings were reported from the central Adriatic Sea (Croatia), Tuscany, Ustica, Ischia Island (off Naples) and Calabria (Italy), from a few centimetres to $10 \mathrm{~m}$ depth, in a variety of habitats: rocky bottoms with a dense macroalgal cover, large cobbles, pebbles, dead matte, Cymodocea nodosa meadows, and sand [139,166-174]. Anchorage of the seedlings, through adhesion by sticky root hairs, is firmer on rocky than on sandy substrates [175]. In Croatia and Tuscany, densities of up to 50 and 60 seedlings per $\mathrm{m}^{2}$, respectively, were recorded [169,171]. In Tuscany, dead matte was the best substrate for the survival of plants proceeding from natural seedling (dead matte $>$ rock > gravel); the 2-year survival rate was better at $10 \mathrm{~m}$ than at $2 \mathrm{~m}$ depth, $70 \%$ vs. $46 \%$, respectively [170]. Overall, mounting evidence, e.g., the high density of natural seedlings, at least in the northwestern Mediterranean and the Adriatic Sea, their survival and development, demonstrates that sexual reproduction and the natural recolonization by seedlings assume a much greater importance than was hitherto believed, at least in the late 20th and early 21st centuries [141,170,176]. 


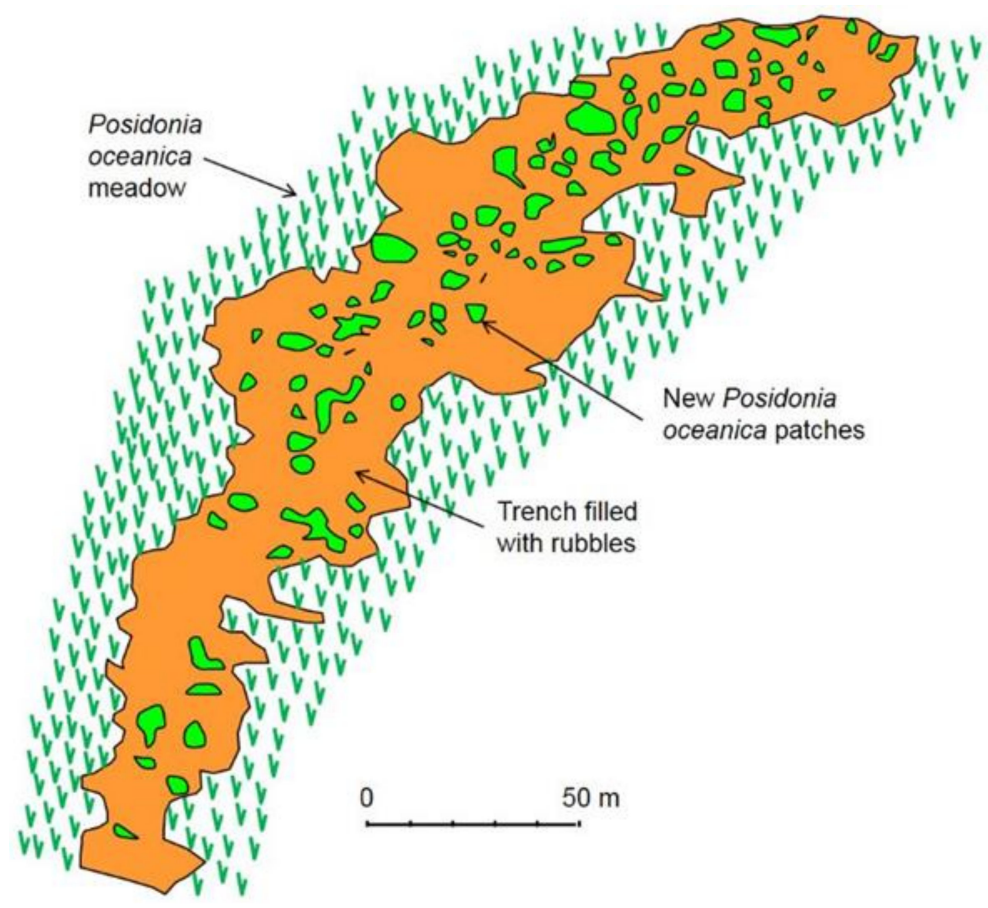

Figure 8. A trench dredged to set up a gas pipeline, then filled with rubbles in 2009, off the harbor at Ischia (Italy). Ten years later, 12\% of the surface area of the trench had been spontaneously recolonized by Posidonia oceanica. From Cotugno et al. [161], redrawn and adapted.

In the 20th century, it was believed that the genetic variability of $P$. oceanica was low, in relation with the scarcity of its flowering $[147,177,178]$. Therefore, the decline of $P$. oceanica was attributed to this low genetic variability. More recent studies have shown that this was not the case: the genetic variability of $P$. oceanica is higher than previously thought, and it even demonstrated the efficiency of its sexual reproduction and the long-distance dispersal of its seeds [179-181].

In contrast with $P$. oceanica, natural recolonization can be relatively rapid in other seagrasses, such as Zostera marina, Z. noltei, C. nodosa, and Ruppia maritima, both in the Mediterranean and elsewhere.

\section{The Techniques of Seagrass Restoration}

Reintroduction is the re-establishment of a species in an area where it has definitely existed in the past, but where it has become locally extinct as a result of human-induced impacts or a reversible natural disaster. Re-stocking is the strengthening of the populations of a species, in a region where it has not disappeared, but where one wishes to restore its former abundance $[182,183]$. Habitat creation establishes new meadows in areas historically uninhabited by a seagrass species $[25,184]$. All the restoration operations that will be discussed here (chapter 5) are in the domain of re-stocking and habitat creation. It is the extent, real in certain regions, of the decline of seagrass meadows, and the slowness, supposed or real, of their natural recolonization, which led to the idea that it could be necessary to proceed to re-stocking or habitat creation, in the Mediterranean $[185,186]$ and worldwide (e.g., [25,36,187-191]).

As stressed by Thoraug [188], the purpose of a restoration attempt for seagrass beds cannot be the laying of end-to-end sods of the seagrasses, but to speed up the process of nature in as rapid a way as possible by cost-efficient means. Seagrass restoration studies date back to 1939, which were largely focused on Zostera marina [25,187,192,193].

Techniques of seagrass re-stocking and habitat creation, usually known as "transplanting", roughly come within seven categories [55,183,194,195]: (i) cement slabs with holes; (ii) cement frames around a wire mesh retaining cuttings; (iii) metallic or plastic wire mesh, laid flat on the bottom, retaining cuttings; (iv) fixing the cuttings to the bottom 
by means of stakes or staples; (v) the digging of holes in which blocks of matte are placed; (vi) the planting of seedlings, germinated in the laboratory; and (vii) finally planting seeds, collected at sea or on beaches.

We have classified these techniques from the most intrusive, those that involve durable artefacts (cement, metal, etc.), to the most ecologically friendly, those that do not use any artefacts. It is clear that our preference is for environmentally-friendly methods.

\subsection{Cement Slabs with Holes}

Cuttings of Posidonia oceanica were placed in the 36 holes of $1-\mathrm{m}^{2}$ cement slabs. We only know of one example of using this very intrusive method [196]: Saint-Mandrier, near Toulon (eastern Provence), at 8-m depth, in a sandy intermatte. The inappropriateness of trying to plant P. oceanica in natural sandy intermattes will be discussed later (Section 5). In addition, cuttings may die, but cement slabs will persist for centuries.

\subsection{Cement Frames around a Wire Mesh Retaining Cuttings}

Cement frames around a wire mesh retaining ortho- and plagiotropic cuttings of P. oceanica were first used in the Bay of Giens (eastern Provence) [197,198]. They were subsequently used in the French Riviera, western Provence, and Italy [194,199-201].

A similar technique was the setting up of small artificial reefs, made of reinforced concrete, with multiple communicating shelters, harboring P. oceanica cuttings; the modules (three types) were placed on hard substrates; the survival of $P$. oceanica cuttings was relatively good [202].

As for cement slabs with holes (Section 4.1), cuttings may die, but cement frames will persist for centuries [183].

\subsection{Metallic, Plastic, or Biodegradable Wire Grid, Laid Flat on the Bottom, Retaining Cuttings}

Wire or plastic grids, laid flat on the bottom and retaining P. oceanica cuttings, have been used in Provence, the French Riviera, Corsica, Tuscany, and Sicily [203-212]. Wire grids were fixed at the corners with $20-70 \mathrm{~cm}$ long steel bars [206]. This method has also been used in Australia, with Posidonia australis [213] and in the United States with Z. marina [214].

A similar technique is the laying down on the bottom of wire bags lined with a geotextile membrane, filled with sand, in which cuttings of $P$. oceanica are placed $[215,216]$. Gabions, i.e., metallic grids filled with rocks, on which cuttings were secured, were used in Sicily $[217,218]$.

\subsection{Fixing the Cuttings to the Bottom by Means of Stakes or Staples}

Fixing the cuttings to the bottom by means of stakes or staples was first used at Beaufort (North Carolina) with Z. marina $[189,190,219]$. This technique has also been used successfully in the Great Bay Estuary (New Hampshire), in the framework of the largest eelgrass transplanting project ever attempted on the east coast of the USA [220], and in Australia with P. australis [191].

This transplanting technique has also been used in the Mediterranean, with P. oceanica) [211,221,222], Cymodocea nodosa, Z. marina, and Zostera noltei [223].

A similar technique was the use of a starch-based biodegradable anchor modular system for transplanting P. oceanica cuttings. Modules were positioned at a depth of $6 \mathrm{~m}$ on sand with C. nodosa and dead matte of P. oceanica; after 20 months, the rate of survival of $P$. oceanica shoots was good [224]. In the same way, cuttings were attached with natural links (sisal) on $1 \mathrm{~m}^{2}$ woven bamboo grids, in Corsica [209]. Coconut biodegradable plant pots, placed upside down with an incision to allow the rhizome of the cutting to penetrate into the sediment below, were used in Greece [222].

In Le Brusc Lagoon (eastern Provence), transplants of $C$. nodosa were fixed to the bottom by means of staples; the $1-\mathrm{m}^{2}$ transplant areas ( 80 in total) were covered by a low 
(20 cm in height) wire cage made of 5-cm mesh, in order to preserve the transplants from grazing by the teleost Sarpa salpa (Figure 9) ([106] Couvray, pers. Comm).
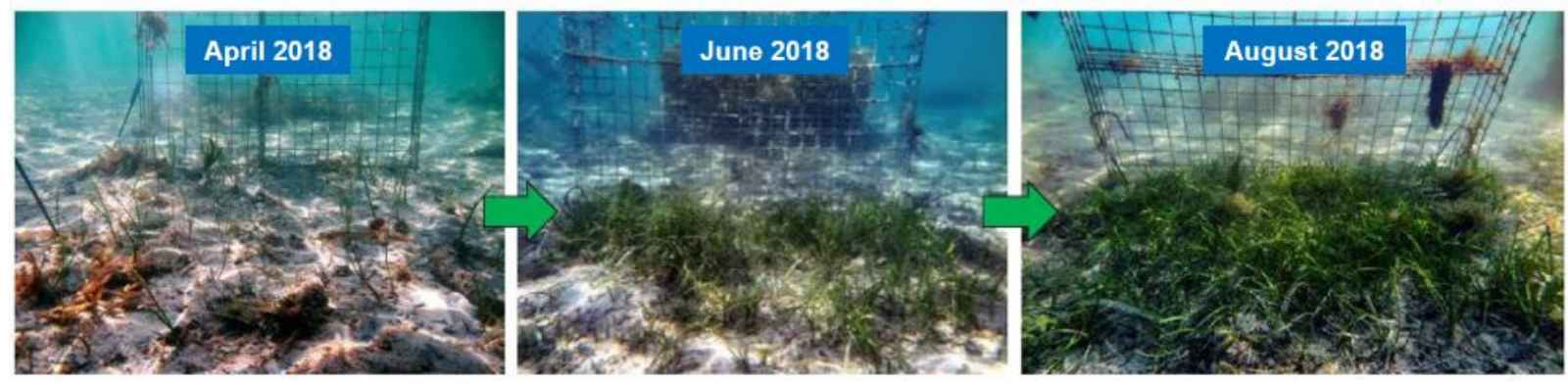

Figure 9. Transplantation of Cymodocea nodosa cuttings in Le Brusc Lagoon (eastern Provence). A wire cage preserves cuttings from Sarpa salpa grazing. For the purposes of photography and monitoring, the cage was raised vertically. From Couvray et al. [106]. ${ }^{\odot}$ IOPR (Institut Océanographique Paul Ricard), courtesy of the authors.

\subsection{The Digging of Holes in which Blocks of Matte are Placed, and Similar Techniques}

Shoots of the eelgrass Zostera marina and the shoalgrass Halodule wrightii were woven into biodegradable paper meshes $(20 \mathrm{~cm} \times 20 \mathrm{~cm})$; this transplanting was intended to mitigate damage to seagrass meadows by scallop dredging in North Carolina $[219,225]$. This technique bypassed logistical problems encountered when handling numerous bulky turfs or plugs of seagrass with attached sediment (see below).

Cylindrical plugs $(20 \mathrm{~cm}$ in diameter, $30 \mathrm{~cm}$ deep, with seagrass intact in the native sediment) were used to transplant Thalassia testudinum and $H$. wrightii in Redfish Bay, Texas [226,227]. This method was also successfully used in the Canary Islands with C. nodosa [228] and in Portugal with Z. marina [36].

In the Mediterranean Sea, cylindrical plugs (plant, roots, and sediment) were used to transplant Zostera noltei in Provence [229-231]. Similar plugs, $20 \mathrm{~cm}$ in diameter, together with individual rhizomes, were used in Venice Lagoon (Italy) to transplant C. nodosa, Z. marina, and Z. noltei $[85,223,232,233]$. Near Ancona (Adriatic Sea, Italy), plugs of Cymodocea nodosa were placed within biodegradable bags and containers [234].

In 2005, before a planned enlargement of the marina at Campomanes (Valencia, Spain), the block of matte technique was used on a much larger scale. Clods of P. oceanica of $1 \mathrm{~m}^{2}$ in surface area and $40 \mathrm{~cm}$ depth lifted with balloons were transported underwater to the transplantation sites, sand intermattes in a P. oceanica meadow, 600 to $1400 \mathrm{~m}$ from the marina; nearly $200 \mathrm{~m}^{2}$ of seagrass were transplanted, with disappointing results: the rate of shoot survival decreased to $15 \%$ after three years [235].

To accommodate cruise ships, the depth of the harbor at Piombino (Liguria) had to be increased. The clods $\left(2.0 \mathrm{~m} \times 1.5 \mathrm{~m} \times 1.2 \mathrm{~m}\right.$; i.e., about $\left.3 \mathrm{~m}^{2}\right)$ were removed from the seabed by a boat crane, carried out using a spilt-barge motor ship and transplanted to a sandy bottom (intermatte channel of a P. oceanica meadow) in Piombino Bay. Overall, $1020 \mathrm{~m}^{2}$ of $P$. oceanica were transplanted. In fact, the clods were simply placed on the sand, forming a kind of hill. The strong point of this technique is (i) that thousands of shoots were transplanted simultaneously and (ii) that the whole of the invertebrate fauna of the shoots and the matte were preserved and transferred with the clod [124].

A similar technique (called "Safebent") was used to transplant P. oceanica blocks (shoots and matte) with a surface area of $0.8 \mathrm{~m}^{2}, 0.6 \mathrm{~m}$ thick, with an average of 130 shoots. It was tested in Monaco in 2017 (Figure 10) $[236,237]$ to relocate, at the government's request, nearly $500 \mathrm{~m}^{2}$ of a P. oceanica meadows threatened with destruction by coastal developments (public land reclamation project). The blocks of matte were placed in metal baskets covered with a biodegradable structure (coconut fiber), transported within the water column (at $10 \mathrm{~m}$ depth) to the transplant sites, between 17 and $20 \mathrm{~m}$ deep, and placed in holes previously dug in a sandy bottom (Figure 11). A different technique was to place the blocks of matte in cement planters, which were built for this purpose on a hard bottom 
(Figure 11). The latter operation is not environmentally-friendly (see Sections 4.1 and 4.2), since the cement structures persist in the event of failure; this was actually the case, since the transplantation ended in failure, and very few shoots survived after three years (in 2020). In contrast, transplants on a sandy substrate had more success after three years: most of the blocks of matte still contained living shoots, and the decrease in the density of the shoots had stabilized, while an increase of plagiotropic rhizomes that tend to colonize the adjacent substrate was observed ([236] Gérard Pergent, unpublished data).
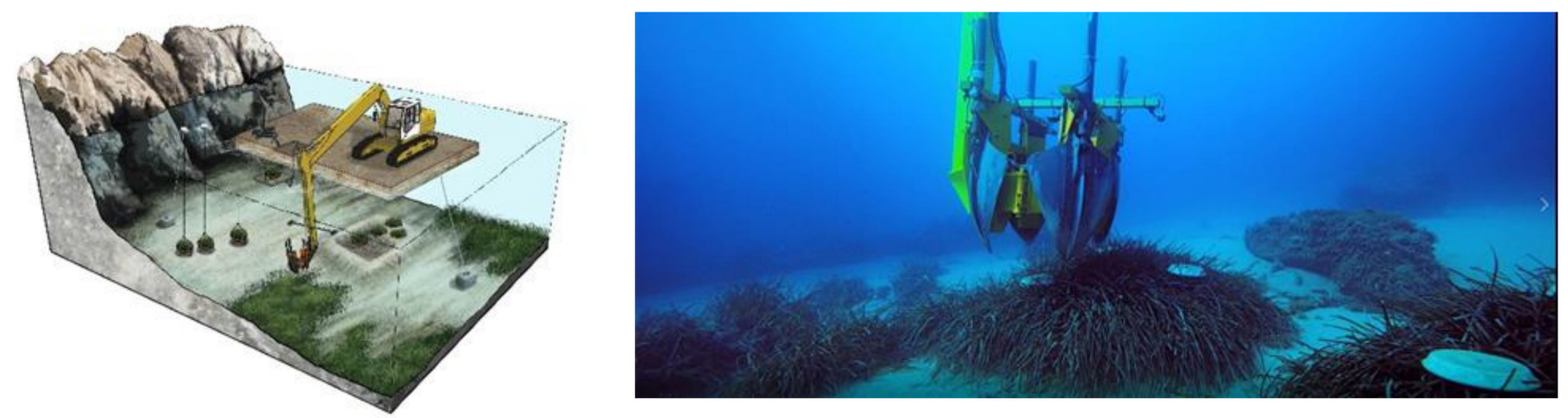

Figure 10. (Left) The excavator, on a pontoon anchored to the bottom. From Descamp et al. [236]. Courtesy of the author. (Right) A view of the clod transplanter in operation. Photo ${ }^{\odot}$ Andromède océanologie. Courtesy of the author.
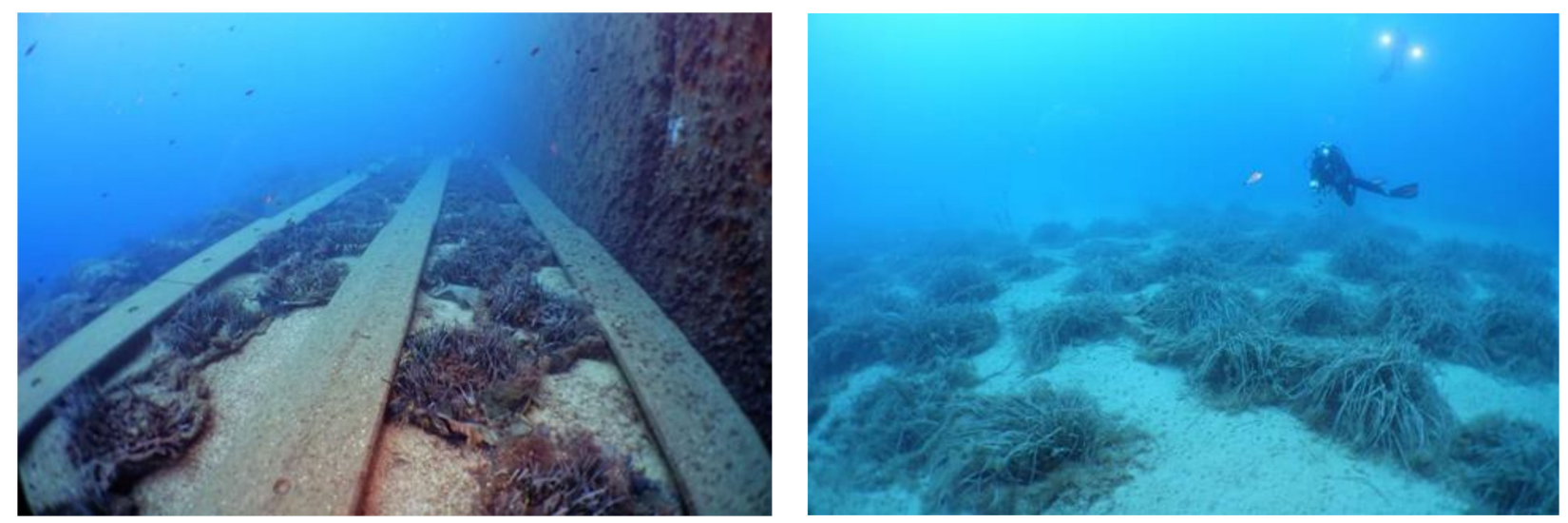

Figure 11. (Left) Cement planters with transplanted clods of matte (Posidonia oceanica), on a hard bottom at Fonvieille (Monaco), $14 \mathrm{~m}$ depth. (Right) The transplant site of Larvotto (Monaco), on a sandy bottom, 17-20 m depth. Photos ${ }^{\circ}$ Jérémie Godefroy, Sectec, courtesy of the author.

In Australia, underwater seagrass harvesting and planting machines ('ECOSUB1' and 'ECOSUB2') were designed to transplant clods (blocks of 'matte'), $0.25 \mathrm{~m}^{2}$ in area and $0.5 \mathrm{~m}$ deep, of Posidonia sinuosa, P. coriacea and Amphibolis griffithii [238].

\subsection{Planting of Seedlings, Germinated in the Laboratory}

The planting of seedlings, germinated in the laboratory, is an ecologically-friendly and low-cost technique that has been used successfully worldwide, with e.g., Z. marina, T. testudinum, and C. nodosa [188,192,239-241]. In the Mediterranean, it has been used with P. oceanica $[22,170,205,207,242]$.

For example, seedlings of P. oceanica, grown under aquarium conditions for six months, were successfully transplanted at Port-Cros Island (Provence) at a depth of $11 \mathrm{~m}$ on a dead matte. They thrived for at least two years [243].

\subsection{Planting Seeds}

Planting seeds, collected at sea or on beaches, is probably the most ecologically friendly technique. It has been successfully used at Hornillo Bay (southern Spain) with P. oceanica 
seeds, at a site where the P. oceanica meadow had been lost as a consequence of fish farming; after two years, the survival rate and leaf development of seedlings planted with mesh-pot anchoring was similar to that of seedlings planted without anchoring [244].

In Virginia (USA), an unparalleled large-scale restoration effort has been maintained annually for 20 years (1999 through 2018) via seed broadcasting of 75 million seeds of Z. marina [245]. In Chesapeake Bay, restored Z. marina meadows, through shoot transplanting and seed planting, exhibited a genetic diversity similar to that of the donor areas [31].

\section{Seagrass Restoration: Where? When? Why?}

\subsection{The Diversity of Ecosystems Does Matter}

Biodiversity means the variety of life, encompassing levels of complexity from within species to across ecosystems. Therefore, biodiversity includes several dimensions [246]. (i) Evolutionary scale, i.e., diversity within species (genetic diversity), diversity between species, diversity between taxa higher than species (genera, families, orders, classes, phyla, kingdoms), and phylogenetic diversity (mean phylogenetic distance between taxa [247]). (ii) Functional scale, i.e., diversity in the functional role of species, functional groups and guilds within ecosystems, e.g., photosynthetic or chemosynthetic primary producers, diazotrophic species, filter feeders, suspension feeders. (iii) Organizational scale, i.e., diversity between patches, communities, ecosystems, landscapes/seascapes, including beta diversity. (iv) Spatial scale, from local and regional to global $[248,249]$. As far as species diversity is concerned (evolutionary scale), it can be considered at the scale of a sample (point diversity) of an ecosystem within a region (alpha diversity), of all the ecosystems of a region (gamma diversity), and of all the ecosystems of a large biogeographic province (epsilon diversity). The spatial (geographic) scale matters a great deal for biodiversity estimates [246,250-252]. (v) In addition, biodiversity includes the proportional distribution of the individuals among the species, the so-called heterogeneity diversity, abundance diversity, or evenness [249].

Biodiversity metrics (more than a hundred) combine several of these scales [246]. It is important to note that the same human-induced impact can increase the value in one metric (for example, the number of species in an ecosystem at the scale of the sample) and reduce it in another metric (for example, the number of species in a region-wide ecosystem). For the general public, biodiversity comes down to the number of species, which is an indicator that is meaningless if it is not combined between several scales [246].

The diversity of ecosystems constitutes an often-neglected scale of biodiversity, while it is (along with functional diversity) one of the most important. This diversity of ecosystems determines the seascape. In addition, coastal ecosystems interact with each other in complex ways (Figure 12). Just as each species plays a role in the ecosystem, so too does each ecosystem play a role in the functioning of the coastal system. There is a complex network of interactions between ecosystems: flows of carbon, of nitrogen, via the litter (e.g., dead Posidonia oceanica leaves) or the migration of individuals. There is also a specialization between ecosystems, some of them being highly productive and exporters, or deficit and importers, and/or spawning sites, nurseries, etc. [6,55,253-255].

For example, sandy bottoms are not deserts that should be transformed into hard substrates (by installing artificial reefs) or meadows (by transplanting seagrasses). The sandy bottoms host an original flora (e.g., diatoms) and an original fauna (e.g., infauna), highly diversified, even if they are less spectacular for the diurnal diver than those of the coralligenous, the seaweed forests, and the P. oceanica meadows. In addition, the sandy bottom ecosystems constitute an important player in the overall balance of the coastal system: e.g., sites of feeding, spawning, and nursery (Figure 12). 


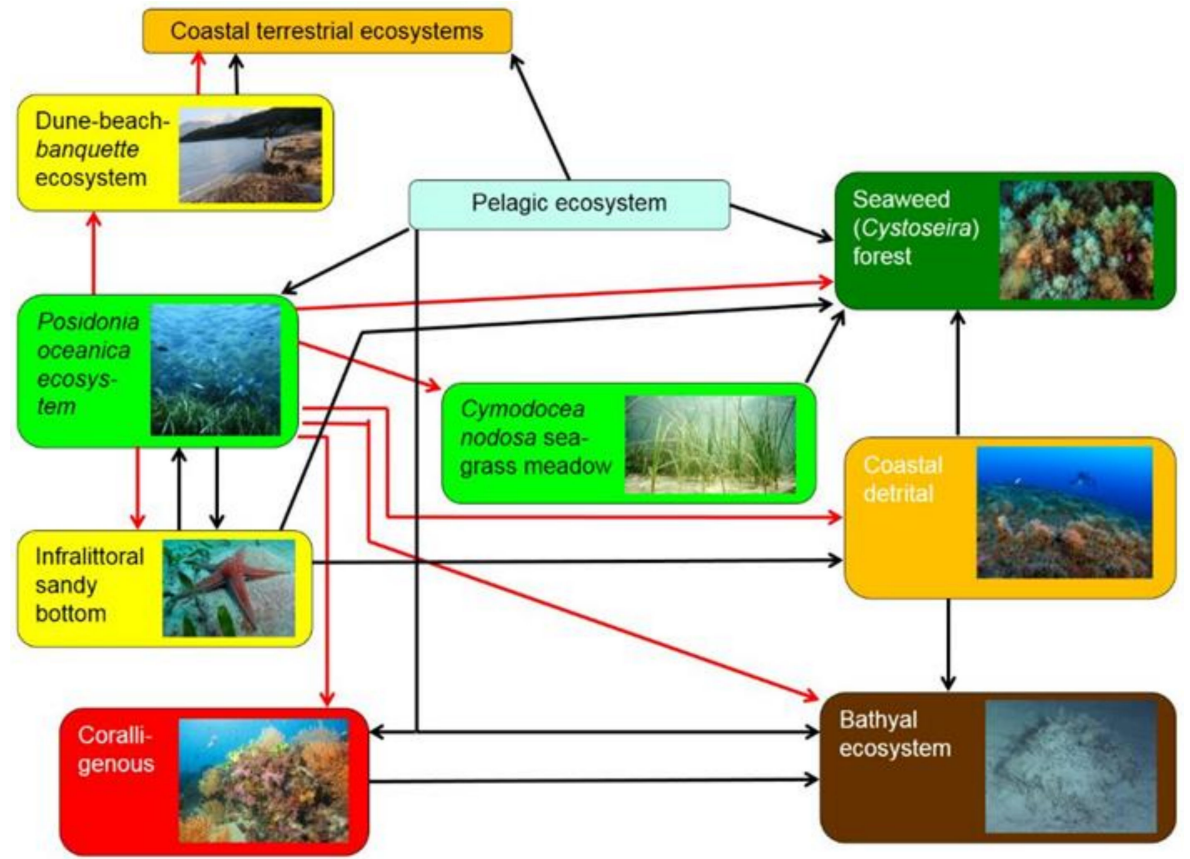

Figure 12. Some interactions between Mediterranean coastal ecosystems. Red arrows: export of litter. Black arrows: other carbon and nitrogen flows. Other interactions are not shown, e.g., nurseries and spawning sites.

\subsection{Seagrass Restoration: Where?}

Before restoring seagrass meadows, it is worth asking the question: is there decline in the region? In some areas, there has been a real decline, for example Zostera marina and Zostera noltei in Berre Lagoon, Cymodocea nodosa in Le Brusc Lagoon of and P. oceanica at Alicante, Marseille, Genoa, and in Liguria in general [76,81,106,108,109,256,257]. In other regions, Corsica and Sicily for example, the decline of P. oceanica is negligible [39,257,258].

Seagrass restoration should not be a business, exploiting literature that is sometimes misinterpretated, but it should be based on real needs at the local level. An emblematic example is that of the Bay of Giens (Provence (see Section 2.1), where dead matte of natural origin has been the target of transplanting attempts $[197,198]$.

Seagrass restoration should follow the cessation of the causes of the regression. Transplanting to an area where the seagrass is still in decline is obviously an absurdity [32,193]. Yet this is what happened at Marseille (Provence) in 2004. The municipality's Environment department had commissioned a study to find out whether P. oceanica planting was possible, and where; the conclusion was that in the west of Prado Bay, the decline had ceased and that therefore, transplanting was possible; on the other hand, in the eastern part of this bay, near the Pointe Rouge marina, the decline continued [66]. However, the public relations department of the same municipality decided to proceed with a highly publicized transplanting operation in front of the marina, the worst possible place; for television purposes, it was considered the most suitable site. Last but not least, the technique used was the worst possible: the use of cement frames (see Section 4.2). All the cuttings died quickly, but there is no doubt that the cement frames will persist on the bottom for decades, perhaps for one century (Charles-François Boudouresque, unpublished data). In Le Brusc Lagoon (eastern Provence), where the collapse of $C$. nodosa is probably due to the overgrazing by the teleost Sarpa salpa, it was thought necessary to install protective wire cages above each of the 80 transplanted quadrats (Figure 9) [106], which constitutes an inappropriate artificialization of the lagoon. It would of course have been better to first try to understand the reasons for the proliferation of $S$. salpa and then, if it was determined that it was not natural to take action to reduce it.

Before planting seagrasses at a site, it is worth asking the question: has the species ever existed there? [32,183]. What justification can there be for trying to replace an infralittoral 
sandy bed (certainly not a biological desert, but the public does not always know this) by e.g., a few clumps of P. oceanica? Such a replacement is in fact a matter of habitat creation, not re-stocking.

For 6000 years, the post-LGM natural rise in sea level has been relatively slow [71,259]. The natural processes of ecological succession have had several millennia in which to act. Therefore, the current mosaic of coastal ecosystems can be considered natural (in the absence of human impact): Cystoseira forest on reef habitats, Posidonia oceanica meadow with sandy intermattes (Figure 2), C. nodosa meadow, sandy habitats, coralligenous, etc. (Figure 12). Of course, this mosaic is not based on the short term (that of a research program, or of a doctoral thesis), nor the medium term (the memory of a researcher; see the concept of shifting baselines and historical amnesia) [260-262], but over the long term, taking into account centennial or millennial storms [263-268]. Unless there is precise and well-argued historical information, relocating a seagrass to a habitat that it did not naturally occupy is an ecological absurdity. However, anticipating the warming of the water can be a valid reason to plant a species in a region where it did not exist previously; this is the case with C. nodosa in Portugal, near its current northern limit [36]. In addition, rejecting transplantation to sites where a seagrass species never occurred may be viewed as somewhat hypocritical, given the extent to which humans have already transformed the planet through other, much more destructive activities. This question deserves consideration in the Mediterranean, although the marine realm has in general been much less transformed by humans than the terrestrial realm. Finally, in Europe, the problem of the public not understanding the values associated with seemingly "barren" ecosystems, that are devoid of more "valued" seagrasses, could partly stem from EU legislation and the 1992 Habitats Directive, which has raised (and in a way deified) the status of seagrasses.

Most of the seagrass transplant operations in the Mediterranean have been carried out in habitats where the transplanted species was not naturally present. The promoters of these transplants are far from following an ecosystem-based approach (see Boudouresque et al. [269]); they consider that there are "noble" ecosystems (such as P. oceanica meadows) and ecosystems of minor importance (for example, sandy bottom ecosystems). Transplanting was done (i) in natural P. oceanica sandy intermattes, such as P. oceanica in the Bay of Piombino (Italy) [124,242], in the Bay of Calvi (Corsica) [270], near Toulon (Provence) [196], and in the Valencia region (Spain) [235]; (ii) on sandy infralittoral bottoms, such as P. oceanica at Larvotto (Monaco) [236] and in Sicily [271], Tuya et al. [22] even proposed surrounding transplanted seedlings with artificial seagrass leaves (a non-natural feature) and showed that this reduced grazing (although obviously a natural feature) and improved the survival rate; (iii) in mud infralittoral habitats not previously colonized, such as Z. noltei at Martigues-Ponteau (western Provence); transplants initially proliferated before being extirpated after three months by a winter storm [229]; (iv) on infralittoral reefs, such as P. oceanica at Fonvieille (Monaco) [236] and in Sicily [202]; (v) in natural C. nodosa meadows, such as P. oceanica at Cannes (French Riviera) and in Sicily [271]; both C. nodosa and P. oceanica are protected species in France; replacing one protected species with another protected species is not a very coherent restoration strategy [183].

An emblematic example is that of the 'Graines de mer' project of the company SM2. The objective was to collect $P$. oceanica seeds, to germinate them in an aquarium, and then to plant them in the sea between La Grande Motte and Frontignan (Occitania, France) in order to create $400 \mathrm{~m}^{2}$ of meadow. This project received $490,000 €$ from a French state agency; it even received a prize awarded by the French Ministry of the Environment ("Prix entreprise et environnement") [272]. Unfortunately, P. oceanica is naturally very rare in Occitania and does not flower there, undoubtedly because of the too low water temperatures and the influence of the Rhone River discharges: it is at the limit of its range area [90]. Therefore, the seeds had to be collected elsewhere; unfortunately, flowering does not occur every year (see Section 3) and did not occur in those years. In any case, wanting to create a $P$. oceanica meadow in a region where the species is naturally rare is a really strange idea. Of course, the project was a total failure; it did not give rise to any publication, or even to any 
document referable to as gray literature. Our reason for citing this tale is (i) to underline the lack of professionalism of state agencies in charge of the environment, and (ii) so that the record of this story will not be forgotten. Funding of nearly half a million euros could undoubtedly have been put to better use for the real protection of seagrasses.

As concerns the transplanting of P. oceanica, the only habitat where such an operation would be justified, from an ecologically ethical point of view (taking into consideration the above-mentioned caveats), is dead matte resulting from human impact, which is exemplified by attempts in Provence [211] and Sicily [43,212,271,273]. The case of trenches opened in a meadow to place a pipeline, then filled with rubble, should be considered; natural recolonization seems relatively rapid [135,161-163]; however, if this were not the case, transplanting would be justified [217]. The transplanting of Z. marina and Z. noltei in Berre Lagoon (Provence) and Venice Lagoon was also justified $[85,231,256,274]$ : the sites chosen have definitely been occupied by Zostera species in the past $[81,85]$, and despite a considerable improvement of the conditions (freshwater discharge, silt input, pollution), the natural spread of Z. marina and Z. noltei is extremely slow; in Berre Lagoon, a regime shift seems to have occurred [11,81].

Habitat creation (see Tan et al. [25]), i.e., transplanting a seagrass species in a habitat that never previously housed the species, and therefore destroying a natural community, must be rejected in most cases (see the above-mentioned caveats). The restoration should not entail the aggravation of the human impact. The only case in which habitat creation would be justified would be if the seagrass species was threatened with extinction in its natural habitats: to our knowledge, this is not the case for any seagrass species in the Mediterranean (LC-Lesat Concern-in the IUCN Red List).

\subsection{Seagrass Restoration as a Pretext for Future Destruction?}

The possibility of planting P. oceanica has often been used as a pretext for destruction, in the context of coastal development projects (new harbors, expansion of existing harbors and marinas, land reclamation)_-"No worries: we are destroying meadows, but we are doing compensatory replanting." The destruction is definitive. On the other hand, planting in habitats where $P$. oceanica never existed may be a failure, in addition to destroying natural habitats (e.g., sandy bottoms), as stressed by several authors $[55,183,235]$.

Therefore, mitigation (or compensatory measures, or even accompanying measures) should only be envisaged as an attempt at restoring approximately what was destroyed in the past, not as a justification for future destruction based on hypothetical compensation $[55,183]$. Furthermore, any compensation measures announced at the time when a development decision is made do not legally commit the developing company, which may not have legal authority or financial resources to put them into effect [183].

The expansion project for the marina at Sanary-sur-Mer (Provence) was accompanied by the planting of a few thousand cuttings of $P$. oceanica, in an area where there was no indication that the species had existed in the past [183]. Fortunately, in France, P. oceanica is a protected species and the law is strictly enforced, which now makes this type of project difficult $[275,276]$. However, the same is not true in other Mediterranean countries, e.g., Monaco and Italy (see for example, Descamp et al. [236] and Bedini et al. [124]).

In most cases, a proposal for planting P. oceanica as a compensatory measure for the destruction of a healthy meadow is a trap and should be rejected. The paving of the bottom with end-to-end cement frames (Figure 13), at Punta San Pietro, Ischia Island (Naples, Italy), as a compensatory measure for the digging of a trench for a gas pipeline [194], is probably the worst example of unethical and inappropriate transplanting operations. 


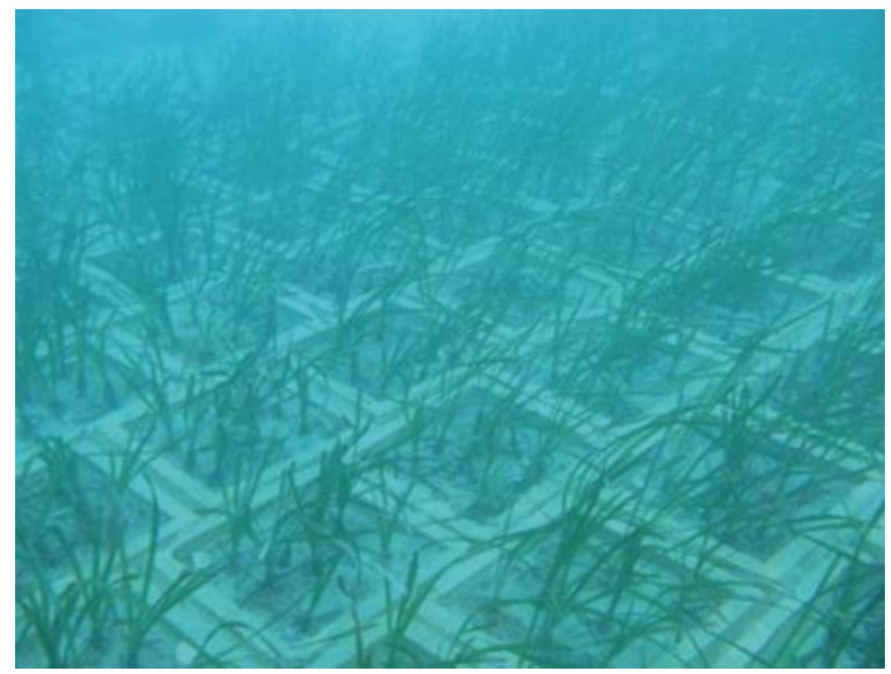

Figure 13. A nightmarish Posidonia oceanica transplanting operation, in the framework of a so-called compensatory measure. Punta San Pietro, Ischia Island, Naples, Italy). From Carannante [194].

In some cases, when a political decision, for example the expansion of the port of Piombino (Liguria) or an offshore urbanization project (Monaco) involves the destruction of a seagrass meadow (P. oceanica), a backup transplant may seem legitimate $[124,236]$. The problem is to find a site for this transplant; generally, the targets of such operations are habitats considered of less importance by managers, such as sandy bottoms, sandy intermattes within a P. oceanica meadow, or seaweed forests on hard substrates (see e.g., [124,236]).

\subsection{Why Restore Seagrass Meadows and When?}

Obviously, seagrass restoration only makes sense if the cause of the decline has disappeared (see Section 5.2). In addition, destroying important ecosystems, such as sand bottoms or rocky reef forests, to replace them with seagrasses makes no sense. It is only on dead P. oceanica matte, when its origin is not natural but due to man, that replanting is justified $[55,183]$. Thus, the restoration of the P. oceanica meadows destroyed over large areas by the anchoring of cruise ships, in the French Riviera [123], which is now banned by French authorities on seagrass meadows or on sites previously occupied by seagrass meadows, is justified.

It is also necessary to consider the surfaces re-implanted vs. the capacity for natural recolonization [125]. The most extensive replanting operations in the Mediterranean are those at Monaco $\left(500 \mathrm{~m}^{2}\right)$ and Piombino $\left(1020 \mathrm{~m}^{2}\right)$ [124,236]. On the Plateau des Chèvres (Marseille), the natural recolonization of an area destroyed by a bomb during World War II extended over $1250 \mathrm{~m}^{2}$ per year (calculation from data of [155-157]. In Prado Bay (Marseille), after the installation of the sewage treatment plant, natural recolonization has amounted to several tens of thousands of $\mathrm{m}^{2}$ per year (Boudouresque, unpublished data). Unfortunately, comparison between the transplanted surface areas and the capacity for natural recolonization by local seagrasses is rarely considered by proponents of replanting operations.

Many authors see themselves as lobbyists for a technique and therefore publish only the most optimistic results. A critical analysis of the results, generally in the case of a failure, is less frequent, as stressed by Bedini et al. [242]. From this point of view, it is worth underlining the ethical aspect of the work concerning the relocation of Z. marina and Z. noltei in Berre Lagoon [231,274]. The authors recognized the poor success of the replanting and the fact that the progression of the transplants was less extensive than that of natural populations.

All in all, transplanting must be integrated within an overall meadow management strategy at the scale of a bay or a region [32,277-280]. This strategy must take into account the following elements $[55,125,183]$ : (i) the total surface area of the existing meadows; 
(ii) the area lost every year due to decline and the causes of this decline; (iii) the area reclaimed each year through natural regeneration (if this occurs); the area that one may hope to reclaim through transplanting, within a 10, 20, or 50 year timescale; (v) the cost of transplanting, and a comparison with the effects of an identical alternative investment in mastering the cause of the decline (sewage treatment, laying anti-trawl reefs, providing ecologically friendly moorings for leisure boats, creating Marine Protected Areas, etc.): seagrass transplanting is worldwide the most expensive restoration method, with a median of 106,782 US\$/ha [25,281]; (vi) lastly, in any case, it is necessary that a trial be done on a small control plot and monitored over at least three years; only a favorable result can justify a large-scale operation.

A decision-making strategy for transplanting P. oceanica and other seagrasses (Figure 14) and a code of conduct (see Box) have been proposed [55,183] (see also [36]). It is regrettable to note that almost no replanting project has used this decision tree, which might be because the answer was obviously "no"? From this point of view, the strategy for selecting P. oceanica transplantation sites implemented in the Gulf of Palermo (Sicily) by Pirrotta et al. [212] is almost unique in the Mediterranean and therefore deserves to be highlighted and praised.

\section{A code of conduct}

To avoid techniques for transplanting Posidonia oceanica being used as a pretext for going ahead with the destruction of existing meadows, a code of good conduct has been proposed, at the request of the French Ministry of the Environment (Boudouresque et al., 1994; Boudouresque, 2001). The main principles are as follows:

1. The exact site and the biotope where the transplanting will be done must have been occupied previously by P. oceanica.

2. The causes of the disappearance of P. oceanica (pollution, trawling, anchorage, etc.) from the site where the transplanting will be done must have ceased to operate. Thus, before any transplanting is done, it must be demonstrated that the meadows or isolated clumps of $P$. oceanica that are nearest to the transplanting site have started a process of natural recolonization.

3. Transplanting must not be done near very extensive meadows. It is useless to add several dozen or hundreds of square metres ( 0.001 to $0.01 \mathrm{ha}$ ) to a meadow consisting of several hundreds or thousands of hectares.

4. Transplanting must not be done to compensate for the destruction of a meadow. To avoid such abuse, no transplanting must be done within a distance of $10 \mathrm{~km}$ from the site of deliberate destruction of a meadow (as part of coastal development) for a 10-year period.

5. However, transplanting on the exact site of the temporary destruction of a meadow may be possible, at least in the countries where the legal protection of $P$. oceanica is not opposed to this. This is the case when an open trench for an archaeological dig is covered over, or a pipe (or cable) crossing a meadow is buried.

6. With the exception of this special case above (point 5), any transplanting of P. oceanica must be undertaken after experimental transplanting of several hundred cuttings; scientific monitoring for at least 3 years must show that the experiment has been a success before a larger scale operation can be envisaged.

7. The removal of cuttings for transplanting must not endanger existing meadows. Therefore, it must be spread over a large area of meadow (less than 2 cuttings $/ \mathrm{m}^{2}$ ). The use of cuttings detached naturally, although giving less good results, or plantlets from seeds, can also be envisaged.

8. Lastly, transplanting must be done within an overall strategy of P. oceanica meadow management of the concerned region.

Similar procedural guides for decision-making, suited to local concerns and species, have been crafted in the US $[282,283]$ and in Australia $[277,284]$. 


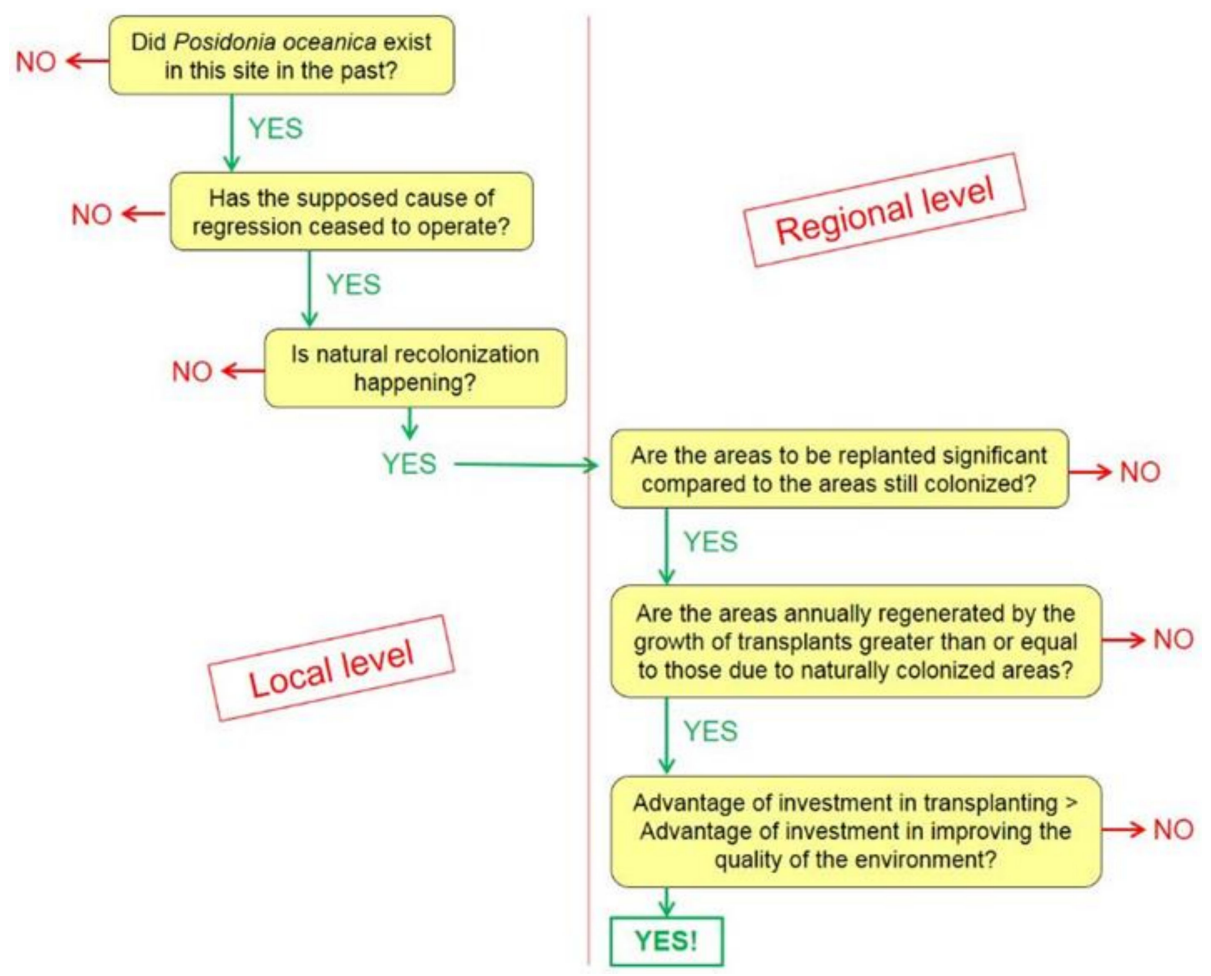

Figure 14. Decision-making strategy for transplanting Posidonia oceanica and other seagrasses. The question-answer sequence first looks at the local level (the site of the anticipated transplanting) and then the regional level (a homogenous area, such as a bay). "No" answer should lead to the project being abandoned. From Boudouresque [183], adapted and redrawn.

Taking into consideration certain genetic, physiological, and morphological parameters can improve the chances of success of the transplanting operation. In P. oceanica, cuttings transplanted from $20 \mathrm{~m}$ to $5 \mathrm{~m}$ depth displayed a better survival rate than those transplanted from 5 to $20 \mathrm{~m}$, perhaps in relation with their carbohydrate content [185]. Plagiotropic (horizontal) rhizomes were more successful than orthotropic ones [206,285,286]. The size of the transplanted plots matters; only the largest plots $\left(11 \mathrm{~m}^{2}\right)$ of Z. marina persisted over a long time in Portugal [36]. The reallocation of nitrogen from leaves and rhizomes to ensure the growth of the roots could constitute a major cause of failure for transplantations [270]. In Australia, the high genetic diversity of the source population of Posidonia australis cuttings has been shown to be a factor of success [287].

Seagrass restoration has been suggested as a Blue Carbon strategy for climate change mitigation. The effectiveness of this strategy remains to be demonstrated [288]. Considering the huge cost of transplants, it is also necessary to question the cost-benefit ratio compared to the strategy of reducing carbon emissions.

\section{Discussion and Conclusions}

A recurring issue with regard to the literature dealing with seagrass restoration in the Mediterranean Sea is that the bulk of the literature deals with techniques, describes experiences on a very local scale, and only concerns the short term [125]: one year $[106,125,208,215,222,234,236,241,270]$, two years $[22,209,217,223,224,231,232]$, three years [124,210,235,256], four years [55,183,242,274], or five years [194], rarely longer [211,212]. The longest monitoring survey (17 to 24 years) does not concern a restoration operation but rather a scientific study of the morphological characters of strains coming from 11 Mediterranean regions (mainland Spain, Balearic Islands, French Catalonia, French Riviera, Corsica, Italy, Malta, Greece, Turkey, and Algeria) and transplanted at the same site in the Port-Cros National Park (Provence) [211]. In contrast with seagrass restoration in North America, where Zostera marina and Thalassia testudinum meadows proceeding from transplanting 
operations can be sighted (e.g., [219,289,290]), in Australia with Posidonia australis [191] and in New Zealand with Zostera muelleri [291], in the Mediterranean, restoration biology is sorely lacking in scientific articles showing a site before (e.g., a dead matte) and after 10 or 15 years (e.g., a lush meadow of Posidonia oceanica). The reason may be due to the functioning of scientific research: the short duration of doctoral thesis projects, short-term funding, the need to publish quickly, the lack of interest of scientific journals and reviewers in what seems routine, etc. However, it may also be surmised that authors, who quickly published results that were not too disappointing (acceptable mortality rate, presence of some plagiotropic rhizomes), were reluctant to publish a report of a definitive failure a few years later. On the basis of an analysis of the literature, Cunha et al. [125] showed that none of the seagrass restoration programs developped in Europe during the 2000s was successful.

In most Mediterranean seagrass restoration programs, a clear stipulation of aspects such as the goals targeted and a quantification of whether or not those goals are met is lacking.

Another problem is that of the preference of politicians, the media, and the general public for grand spectacle, high profile, possibly colossal scale, operations. Budgets are limited for the protection of non-iconic species and for the improvement of the conditions of their environment; they are unlimited when the aim is to enable man, deus ex machina, to take control of the environment. To say that it is best to allow nature to take its course, that nature generally does things better than humans (and for free!), as stressed by Leakey and Lewin [292], and Schnitzler et al. [293], is often unacceptable to politicians and managers of state agencies. The case of the obviously unrealistic project to create P. oceanica meadows in Occitania [272] is the perfect example of this. Fortunately, some operations perfectly meet the requirements of the code of conduct, such as the widespread transplantation of small sods and individual rizomes of seagrasses (mainly Z. marina and Z. noltei) in the northern part of the Venice Lagoon; in addition, this operation engaged the local population in the restoration of the environment, making the action not only environmentally friendly (methods) but also economically inexpensive [85].

In any case, the decline of some species of seagrasses, in certain regions of the Mediterranean, is a worrying reality. As part of a regional strategy, relocation may be justified, provided that the most environmentally friendly techniques are used. The regional strategy must take into account (i) natural recolonization vs. assisted recolonization; priority should be given to natural restoration potential, with an emphasis on the fact that restoration should never be considered the first alternative [125]; (ii) the cost of relocation vs. an equivalent investment in improving environmental conditions (e.g., ecologically friendly anchoring, sewage treatment, prohibition of trawling and of anchoring of cruise ships, ban on the creation or expansion of harbors and marinas, ban on the removal of P. oceanica banquette on beaches, etc.); (iii) and of course, the imperative of only replanting (in most cases) in areas formerly colonized by the species concerned; destroying an ecosystem that is believed to be of minor importance, but which plays a role in the functioning of the coastal system, in order to plant a seagrass that was not naturally present there, is not very coherent from an ecological point of view.

Unfortunately, the vast majority (but not all) of seagrass restoration projects in the Mediterranean Sea do not meet these obvious, basic criteria. This perhaps explains the extreme rarity of success stories in the seagrass restoration field. Moreover, is there a single example of medium-term success (say 10-20 years) in the Mediterranean?

Elliott et al. [184] emphasized that the few success stories in restoring habitats concern marginal or semi-enclosed areas such as coastal bays, estuaries, and fringing habitats; they refer less frequently to open coastal and marine habitats. The best option available in the latter is usually to remove the stressor, to prevent other stressors from operating, and to allow the conditions suitable for natural recovery $[184,235]$.

The relative failure of seagrass restoration in the Mediterranean is often compared to successes in other parts of the world ocean, as illustrated by the restoration of Z. marina 
meadows [245]. Yet, these successes deserve to be re-examined with a critical eye. The losses were partly of natural origin (wasting disease, tropical storms); in the absence of human impact, natural recolonization was often relatively rapid. An accurate comparison of natural and unassisted vs. assisted recolonization is often missing. Was the effort (and money) deployed to try to do better, or faster, than nature really justified? Would not this money and this effort have been more effectively deployed in reducing human impacts? This question of the real cost and benefits balance of seagrass restoration operations is in fact insufficiently addressed by the authors. The myth of man as superior to nature, developed by 18th and 19th century authors (see Boudouresque et al. [269]), is still alive and well present in the 21st century.

Author Contributions: Conceptualization (C.-F.B.), writing (A.B., C.-F.B., G.P. and T.T.). All authors have read and agreed to the published version of the manuscript.

Funding: This research received no external funding.

Institutional Review Board Statement: Not applicable.

Informed Consent Statement: Not applicable.

Data Availability Statement: The data presented in this study are available on request from the corresponding author.

Acknowledgments: The authors are indebted to Michael Paul, a native English speaker, for proofreading the text and to Michèle Perret-Boudouresque for bibliographical assistance. They are also grateful to Patrick Astruch (GIS Posidonie), Marc Verlaque (Mediterranean Institute of Oceanography), and Alexandre Meinesz (University of Nice) for unpublished data and valuable suggestions, and to Sylvain Coudray (Institut Océanographique Paul Ricard) for valuable data dealing with Le Brusc Lagoon (eastern Provence). The authors would like to thank Andromede Oceanologie and the Government of Monaco for the permission to use, sometimes critically, documents concerning transplants performed in Monaco. Finally, the authors are endebted to three anonymous reviewers for their valuable suggestions.

Conflicts of Interest: The authors declare no conflict of interest.

\section{References}

1. Christenhusz, M.J.M.; Byng, J.W. The number of known plant species in the world and its annual increase. Phytotaxa 2016, 261, 201-217. [CrossRef]

2. Chambers, P.A.; Lacoul, P.; Murphy, K.J.; Thomaz, S.M. Global diversity of aquatic macrophytes in freshwater. Hydrobiologia 2008, 595, 9-26. [CrossRef]

3. den Hartog, C.; Kuo, J. Taxonomy and biogeography of seagrasses. In Seagrass Biology, Ecology and Conservation; Larkum, A.W.D., Orth, R.J., Duarte, C.M., Eds.; Springer: Berlin/Heidelberg, Germany, 2006; pp. 1-23.

4. Guiry, M.D.; Guiry, G.M. Ruppia maritima. In AlgaeBase; World-Wide Electronic Publication, National University of Ireland: Galway, Ireland, 2020; Available online: https:/ /www.algaebase.org (accessed on 14 December 2020).

5. Fourqurean, J.W.; Duarte, C.M.; Kennedy, H.; Marbà, N.; Holmer, M.; Mateo, M.A.; Apostolaki, E.T.; Kendrick, G.A.; KrauseJensen, D.; Mcglathery, K.J.; et al. Seagrass ecosystems as a globally significant carbon stock. Nat. Geosci. 2012, 5, 505-509. [CrossRef]

6. Boudouresque, C.F.; Pergent, G.; Pergent-Martini, C.; Ruitton, S.; Thibaut, T.; Verlaque, V. The necromass of the Posidonia oceanica seagrass meadow: Fate, role, ecosystem services and vulnerability. Hydrobiologia 2016, 781, 25-42. [CrossRef]

7. Johannessen, S.C.; Macdonald, R.W. Geoengineering with seagrasses: Is credit due where credit is given? Environ. Res. Lett. 2016, 11, 1-10. [CrossRef]

8. Nordlund, L.M.; Koch, E.W.; Barbier, E.B.; Creed, J.C. Seagrass ecosystem services and their variability across genera and geographical regions. PLoS ONE 2016, 11, e0163091. [CrossRef]

9. de Falco, G.; Molinaroli, E.; Conforti, A.; Simeone, S.; Tonielli, R. Biogenic sediments from coastal ecosystems to Beach-Dune Systems: Implications for the adaptation of mixed and carbonate beaches to future sea level rise. Biogeosciences 2017, 14, 3191-3205. [CrossRef]

10. Pergent-Martini, C.; Pergent, G.; Monnier, B.; Boudouresque, C.F.; Mori, C.; Valette-Sansevin, A. Contribution of Posidonia oceanica meadows in the context of climate change mitigation in the Mediterranean Sea. Mar. Environ. Res. 2021, 165, 105236. [CrossRef]

11. Boudouresque, C.F.; Bernard, G.; Pergent, G.; Shili, A.; Verlaque, M. Regression of Mediterranean seagrasses caused by natural processes and anthropogenic disturbances and stress: A critical review. Bot. Mar. 2009, 52, 395-418. [CrossRef]

12. Ruíz, J.M.; Boudouresque, C.F.; Enríquez, S. Mediterranean seagrasses. Bot. Mar. 2009, 52, 369-382. [CrossRef] 
13. Boudouresque, C.F.; Verlaque, M. Does the seagrass Posidonia really occur in Madagascar? Phycologia 2008, 47, 435-436. [CrossRef]

14. Shili, A.; Ben Maiz, N.; Boudouresque, C.F.; Trabelsi, E.B. Abrupt changes in Potamogeton and Ruppia beds in a Mediterranean lagoon. Aquat. Bot. 2007, 87, 181-188. [CrossRef]

15. Por, F.D. Lessepsian Migrations: The Influx of Red Sea Biota into the Mediterranean by Way of the Suez Canal; Springer: Berlin/Heidelberg, Germany, 1978; pp. 8-228.

16. Gerakaris, V.; Lardi, P.I.; Issaris, Y. First record of the tropical seagrass species Halophila decipiens Ostenfeld in the Mediterranean Sea. Aquat. Bot. 2020, 160, 103151. [CrossRef]

17. Winters, G.; Beer, S.; Willette, D.A.; Viana, I.G.; Chiquillo, K.L.; Beca-Carretero, P.; Villamayor, B.; Azcárate-García, T.; Shem-Tov, R.; Mwabvu, B.; et al. The tropical seagrass Halophila stipulacea: Reviewing what we know from its native and invasive habitats, alongside identifying knowledge gaps. Front. Mar. Sci. 2020, 7, 1-28. [CrossRef]

18. Orth, R.J.; Carruthers, T.J.B.; Dennison, W.B.; Duarte, C.M.; Fourqurean, J.W.; Heck, K.L., Jr.; Hughes, A.R.; Hendrick, G.A.; Kenworthy, W.J.; Olyarnik, S.; et al. A global crisis for seagrass ecosystems. BioScience 2006, 56, 987-996. [CrossRef]

19. Waycott, M.; Duarte, C.M.; Carruthers, T.J.B.; Orth, R.J.; Dennison, W.C.; Olyarnik, S.; Calladine, A.; Fourqurean, J.W.; Heck, K.L., Jr.; Hughes, A.R.; et al. Accelerating loss of seagrasses across the globe threatens coastal ecosystems. Proc. Natl. Acad. Sci. USA 2009, 106, 12377-12381. [CrossRef]

20. Coles, R.; Grech, A.; McKenzie, L. Seagrass under pressure. Seagrass Watch 2013, 47, 2-6.

21. Unsworth, R.K.F.; van Keulen, M.; Coles, R.G. Seagrass meadows in a globally changing environment. Mar. Pollut. Bull. 2014, 83, 383-386. [CrossRef]

22. Tuya, F.; Vila, F.; Bergasa, O.; Zarranz, M.; Espino, F.; Robaina, R.R. Artificial seagrass leaves shield transplanted seagrass seedlings and increase their survivorship. Aquat. Bot. 2017, 136, 31-34. [CrossRef]

23. Cullen-Unsworth, L.C.; Unsworth, R. A call for seagrass protection. Science 2018, 261, 446-447.

24. de Los Santos, C.B.; Krause-Jensen, D.; Alcoverro, T.; Marbà, N.; Duarte, C.M.; van Katwijk, M.M.; Pérez, M.; Romero, J.; Sanchez-Lizaso, J.L.; Roca, G.; et al. Recent trend reversal for declining European seagrass meadows. Nat. Commun. 2019, 10, 1-8. [CrossRef] [PubMed]

25. Tan, Y.M.; Dalby, O.; Kendrick, G.A.; Statton, J.; Sinclair, E.A.; Fraser, M.W.; MacReadie, P.I.; Gillies, C.L.; Coleman, R.A.; Waycott, M.; et al. Seagrass restoration is possible: Insights and lessons from Australia and New Zealand. Front. Mar. Sci. 2020, 7, 1-21. [CrossRef]

26. den Hartog, C. The Sea-Grasses of the World; North-Holland Publishing Company: Amsterdam, The Netherlands, $1970 ;$ p. 275.

27. Short, F.T.; Ibelings, B.W.; den Hartog, C. Comparison of a current eelgrass disease to the wasting disease in the 1930s. Aquat. Bot. 1988, 30, 295-304. [CrossRef]

28. Giesen, W.B.J.T.; van Katwijk, M.M.; den Hartog, C. Eelgrass condition and turbidity in the Dutch Wadden Sea. Aquat. Bot. 1990, 37, 71-85. [CrossRef]

29. den Hartog, C. Sudden declines of seagrass beds: 'Wasting disease' and other disasters. In Seagrass Biology: Proceedings of an International Workshop, Rottnest Island, Australia, 25-29 January 1996; Kuo, J., Phillips, R.C., Walker, D.I., Kirkman, H., Eds.; University Western Australia: Perth, Australia, 1996; pp. 307-314.

30. Ralph, P.J.; Short, F.T. Impact of the wasting disease pathogen, Labyrinthula zosterae, on the photobiology of eelgrass Zostera marina. Mar. Ecol. Prog. Ser. 2002, 226, 265-271. [CrossRef]

31. Williams, S.L.; Orth, R.J. Genetic diversity and structure of natural and transplanted eelgrass populations in the Chesapeake and Chincoteague Bays. Estuaries 1998, 21, 118-128. [CrossRef]

32. van Katwijk, M.M.; Bos, A.R.; de Jonge, V.N.; Hanssen, L.S.A.M.; Hermus, D.C.R.; de Jonge, D.J. Guidelines for seagrass restoration: Importance of habitat selection and donor population, spreading of risks, and ecosystem engineering effects. Mar. Pollut. Bull. 2009, 58, 179-188. [CrossRef]

33. Rueda, J.L.; Urra, J.; Marina, P.; Mateo, Á.; Salas, C.; Gofas, S. Loss of Zostera marina in southern Spain and effects on its associated molluscan assemblage. In Proceedings of the 4th Mediterranean Symposium on Marine Vegetation, Yasmine-Hammamet, Tunisia, 2-4 December 2010; El Asmi, S., Langar, H., Belkacem, W., Eds.; RAC/SPA Publications: Tunis, Tunisia, $2010 ;$ pp. $212-214$.

34. Auby, I.; Rigouin, L.; Trut, G.; Oger-Jeanneret, H.; Ganthy, F.; Trut, F.; Gouriou, L.; Bujan, S.; Devaux, L.; Gouillieux, B.; et al. Suivi Stationnel (2006-2015) des Herbiers de Zostères (Zostera noltei et Zostera marina) et Calcul de L'indicateur 'Angiospermes' (2015) Dans la Masse D'eau Côtière FRFC06-Arcachon Amont_Bassin Hydrographique Adour-Garonne; Ifremer Publications: Paris, France, 2016 ; p. 50.

35. Lefcheck, J.S.; Orth, R.J.; Dennison, W.C.; Wilcox, D.J.; Murphy, R.R.; Keisman, J.; Gurbisz, C.; Hannam, M.; Landry, J.B.; Moore, K.A.; et al. Long-term nutrient reductions lead to the unprecedented recovery of a temperate coastal region. Proc. Natl. Acad. Sci. USA 2018, 115, 3658-3662. [CrossRef]

36. Paulo, D.; Cunha, A.H.; Boavida, J.; Serrão, E.A.; Gonçalves, E.J.; Fonseca, M. Open coast seagrass restoration. Can we do it? Large scale seagrass transplants. Front. Mar. Sci. 2019, 6, 1-15. [CrossRef]

37. Walter, R.K.; O'Leary, J.K.; Vitousek, S.; Taherkhani, M.; Geraghty, C.; Kitajima, A. Large-scale erosion driven by intertidal eelgrass loss in an estuarine environment. Estuar. Coast. Shelf Sci. 2020, 243, 1-7. [CrossRef]

38. González-Correa, J.M.; Bayle-Sempere, J.T.; Sánchez-Jerez, P.; Valle, C. Posidonia oceanica meadows are not declining globally. Analysis of population dynamics in marine protected areas of the Mediterranean Sea. Mar. Ecol. Prog. Ser. 2007, 336, 111-119. [CrossRef] 
39. Bonacorsi, M.; Pergent-Martini, C.; Bréand, N.; Pergent, G. Is Posidonia oceanica regression a general feature in the Mediterranean Sea? Mediterr. Mar. Sci. 2013, 14, 193-203. [CrossRef]

40. Leriche, A.; Pasqualini, V.; Boudouresque, C.F.; Bernard, G.; Bonhomme, P.; Clabaut, P.; Denis, J. Spatial, temporal and structural variations of a Posidonia oceanica seagrass meadow facing human activities. Aquat. Bot. 2006, 84, 287-293. [CrossRef]

41. Boero, F. Scientists can be free, but only once they are tenured. Ethics Sci. Environ. Politics 2015, 15, 63-69. [CrossRef]

42. Duarte, C.M.; Fulweiler, R.W.; Lovelock, C.E.; Martinetto, P.; Saunders, M.I.; Pandolfi, J.M.; Gelcich, S.; Nixon, S.W. Reconsidering ocean calamities. BioScience 2015, 65, 130-139. [CrossRef]

43. Calvo, S.; Pirrotta, M.; Tomasello, A. Letter to the editor regarding the article "Taking advantage of seagrass recovery potential to develop novel and effective meadow rehabilitation methods" by Alagna et al., published in Marine Pollution Bulletin, 149: 2019 (110578). Mar. Pollut. Bull. 2020, 158, 1-5. [CrossRef]

44. Lejeusne, C.; Chevaldonné, P.; Pergent-Martini, C.; Boudouresque, C.F.; Perez, T. Climate change effects on a miniature ocean: The highly diverse, highly impacted Mediterranean Sea. Trends Ecol. Evol. 2010, 25, 250-260. [CrossRef]

45. Leriche, A.; Boudouresque, C.F.; Bernard, G.; Bonhomme, P.; Denis, J. A one-century suite of seagrass bed maps: Can we trust ancient maps? Estuar. Coast. Shelf Sci. 2004, 59, 353-362. [CrossRef]

46. Astruch, P.; Boudouresque, C.F.; Bonhomme, D.; Goujard, A.; Antonioli, P.A.; Bonhomme, P.; Perez, T.; Ruitton, S.; de Saint-Martin, T.; Verlaque, M. Mapping and state of conservation of benthic marine habitats and assemblages of Port-Cros National Park (Provence, France, Northwestern Mediterranean Sea). Sci. Rep. Port-Cros Natl. Park 2012, 26, 45-90.

47. Pergent-Martini, C.; Valette, A.; Damier, É.; Pergent, G. L'évaluation surfacique des habitats est-elle un indicateur fiable de la dynamique spatio-temporelle en milieu marin? In Proceedings of the Colloque National de Cartographie des Habitats Marins: CARAMB'AR, Brest, France, 14-16 March 2017; pp. 98-101.

48. Valette-Sansevin, A.; Pergent, G.; Buron, K.; Damier, E.; Pergent-Martini, C. Continuous mapping of benthic habitats along the coast of Corsica: A tool for the inventory and monitoring of blue carbon ecosystems. Mediterr. Mar. Sci. 2019, 20, 585-593. [CrossRef]

49. Pasqualini, V.; Pergent-Martini, C.; Pergent, G. Mediterranean coastal resources management: The example of the Island of Corsica. In Proceedings of the Fourth International Conference: Remote Sensing for Marine and Coastal Environments, Technology and Applications, Orlando, FL, USA; 1997; Volume 1, pp. 632-640.

50. Paillard, M.; Gravez, V.; Clabaut, P.; Walker, P.; Blanc, J.J.; Boudouresque, C.F.; Belsher, T.; Urscheler, F.; Poydenot, F.; Sinnassamy, J.M.; et al. Cartographie de L'herbier de Posidonie et des Fonds Marins Environnants de Toulon à Hyères (Var, France). Reconnaissance par Sonar Latéral et Photographie Aérienne. Notice de Présentation; IFREMER and GIS Posidonie Publications: Marseille, France, 1993; p. 36.

51. Andromede Oceanologie. La Méditerranée Dévoile ses Dessous_Cartographie Continue des Habitats Marins; Partenariat Agence de L'EAU RMC-Andromède: Marseille, France, 2014.

52. Astier, J.M.; Taillez, P. Pour un plan d'occupation des fonds marins: Inventaire des herbiers de posidonies du littoral du Var. Ann. Soc. Sci. Nat. Archéol. Toulon Var 1984, 36, 35-46.

53. Belsher, T.; Houlgatte, E.; Boudouresque, C.F. Cartographie de la prairie à Posidonia oceanica et des principaux facies sédimentaires marins du Parc national de Port-Cros (Var, France, Méditerranée). Sci. Rep. Port-Cros Natl. Park 2005, 21, 19-28.

54. Molinier, R.; Picard, J. Recherches sur les herbiers de Phanérogames marines du littoral méditerranéen français. Ann. Inst. Océanogr. 1952, 27, 157-234.

55. Boudouresque, C.F.; Bernard, G.; Bonhomme, P.; Charbonnel, E.; Diviacco, G.; Meinesz, A.; Pergent, G.; Pergent-Martini, C.; Ruitton, S.; Tunesi, L. Protection and Conservation of Posidonia oceanica Meadows; RAMOGE and RAC/SPA Publications: Tunis, Tunisia, 2012; p. 202.

56. Libes, M.; Boudouresque, C.F. Uptake and long-distance transport of carbon in the marine phanerogam Posidonia oceanica. Mar. Ecol. Prog. Ser. 1987, 38, 177-186. [CrossRef]

57. Tomasello, A.; Calvo, S.; Di Maida, G.; Lovison, G.; Pirrotta, M.; Sciandra, M. Shoot age as a confounding factor on detecting the effect of human-induced disturbance on Posidonia oceanica growth performance. J. Exp. Mar. Biol. Ecol. 2007, 343, 166-175. [CrossRef]

58. Boudouresque, C.F.; Jeudy de Grissac, A.; Meinesz, A. Un nouveau type d'herbier à Posidonia oceanica: L'herbier de colline. Rapp . Comm. Int. Mer Mediterr. 1985, 29, 173-175.

59. Boudouresque, C.F.; Thommeret, J.; Thommeret, Y. Sur la Découverte D'un Bioconcrétionnement Fossile Intercalé dans L'herbier à Posidonia oceanica de la Baie de Calvi (Corse); CIESM Publications: Monaco, Monaco, 1980; pp. 139-142.

60. Diviacco, G.; Virno-Lamberti, C.; Spada, E. Osservazioni sulla prateria di Posidonia oceanica (L.) Delile di 'Marina di Tarquinia' (Lazzio settentrionale). Biol. Mar. Mediterr. 1999, 6, 496-499.

61. Diviacco, G.; Spada, E.; Virno-Lamberti, C. Le Fanerogame marine del Lazio. Descrizione e Cartografia Delle Praterie di Posidonia oceanica e Dei Prati di Cymodocea Nodosa; ICRAM Publications: Rome, Italy, 2001; p. 113.

62. Abadie, A.; Gobert, S.; Bonacorsi, M.; Lejeune, P.; Pergent, G.; Pergent-Martini, C. Marine space ecology and seagrasses. Does patch type matters in Posidonia oceanica seascape? Ecol. Indic. 2015, 57, 435-446. [CrossRef]

63. Gobert, S.; Lepoint, G.; Pelaprat, C.; Remy, F.; Lejeune, P.; Richir, J.; Abadie, A. Temporal evolution of sand corridors in a Posidonia oceanica seascape: A 15-year study. Mediterr. Mar. Sci. 2016, 17, 777-784. [CrossRef] 
64. Pergent, G.; Calvo, S.; Cancemi, G.; Djellouli, A.; Dupuy de La Granrive, R.; Langar, H.; Pergent-Martini, C.; Tomasello, A. Nouvelles Connaissances sur les Herbiers Tigrés de Méditerranée. In Proceedings of the 4th Mediterranean Symposium on Marine Vegetation, Yasmine-Hammamet, Tunisia, 2-4 December 2010; El Asmi, S., Langar, H., Belkacem, W., Eds.; RAC/SPA Publications: Tunis, Tunisia, 2010; pp. 95-98.

65. Coppa, S.; Quattrocchi, G.; Cucco, A.; de Lucia, G.A.; Vencato, S.; Camedda, A.; Domenici, P.; Conforti, A.; Satta, A.; Tonielli, R.; et al. Self-organisation in striped seagrass meadows affects the distributional pattern of the sessile bivalve Pinna nobilis. Sci. Rep. 2019, 9, 1-15. [CrossRef]

66. Gravez, V.; Nieri, M.; Boudouresque, C.F. Surveillance de L'herbier de Posidonie de La Baie du Prado (Marseille). Rapport de Synthèse 1986-1992; Direction Générale des Services Techniques de La Ville de Marseille et GIS Posidonie Publications: Marseille, France, 1992; p. 80.

67. Boudouresque, C.F.; Astruch, P.; Goujard, A.; Rouanet, É; Bonhomme, D.; Bonhomme, P. The withdrawal of the lower limit of the Posidonia oceanica seagrass meadow in the Bay of Hyères (NW Mediterranean): A combination of natural and human-induced recent and ancient phenomena? In Proceedings of the 6th Mediterranean Symposium on Marine Vegetation, Antalya, Turkey, 14-15 January 2019; Langar, H., Ouerghi, A., Eds.; RAC/SPA Publications: Tunis, Tunisia, 2019; pp. 35-40.

68. Henderson, G.M. Coral clues to rapid sea-level change. Science 2005, 308, 361-362. [CrossRef]

69. Lichter, M.; Zviely, D.; Klein, M.; Sivan, D. Sea-level changes in the Mediterranean: Past, present and future-A review. In Seaweeds and Their Role in Globally Changing Environments; Israel, A., Einav, R., Seckbach, J., Eds.; Springer: Dordrecht, The Netherlands, 2010; pp. 5-17.

70. Vacchi, M.; Ghilardi, M.; Spada, G.; Currás, A.; Robresco, S. New insights into the sea-level evolution in Corsica (NW Mediterranean) since the late Neolithic. J. Archaeol. Sci. Rep. 2017, 12, 782-793. [CrossRef]

71. Laborel, J.; Morhange, C.; Lafont, R.; Le Campion, J.; Laborel-Deguen, F.; Sartoretto, S. Biological evidence of sea-level rise during the last 4500 years on the rocky coasts of continental southwestern France and Corsica. Mar. Geol. 1994, 120, 203-223. [CrossRef]

72. Miller, K.G.; Kominz, M.A.; Browning, J.V.; Wright, J.D.; Mountain, G.S.; Katz, M.E.; Sugarman, P.J.; Cramer, B.S.; Christie-Blick, N.; Pekar, S.F. The Phanerozoic record of global sea-level change. Science 2005, 310, 1293-1298. [CrossRef]

73. Blanc, J.J.; Jeudy de Grissac, A. Recherches de Géologie Sédimentaire sur Les Herbiers à Posidonies du Littoral de la Provence; CNEXO Publications: Paris, France, 1978; p. 185.

74. Deter, J.; Guibert, A.; Freschet, E.; Boissery, P.; Holon, F. Assessment on 90 years of coastal development in France and consequences for Posidonia oceanica beds. Rapp. Comm. Int. Mer Mediterr. 2013, 40, 520.

75. Holon, F.; Boissery, P.; Guilbert, A.; Freschet, E.; Deter, J. The impact of 85 years of coastal development on shallow seagrass beds (Posidonia oceanica L. (Delile)) in South Eastern France: A slow but steady loss without recovery. Estuar. Coast. Shelf Sci. 2015, 165, 204-212. [CrossRef]

76. Ramos-Esplá, A.A.; Aranda, A.; Gras, D.; Guillen, J.E. Impactos sobre las praderas de Posidonia oceanica (L.) Delile en el SE español: Necesidad de establecer herramientas de ordenamiento y gestión del litoral. In Pour Qui la Méditerranée au 21 Siècle ? Villes des Rivages et Environnement Littoral en Méditerranée; Ville de Montpellier Publications: Montpellier, France, 1994; pp. 64-69.

77. Peirano, A.; Damasso, V.; Montefalcone, M.; Morri, C.; Bianchi, C.N. Effects of climate, invasive species and anthropogenic impacts on the growth of the seagrass Posidonia oceanica (L.) Delile in Liguria (NW Mediterranean Sea). Mar. Pollut. Bull. 2005, 50, 817-822. [CrossRef]

78. Telesca, L.; Belluscio, A.; Criscoli, A.; Ardizzone, G.; Apostolaki, E.T.; Fraschetti, S.; Gristina, M.; Knittweis, L.; Martin, C.S.; Pergent, G.; et al. Seagrass meadows (Posidonia oceanica) distribution and trajectories of change. Sci. Rep. 2015, 5, 1-14. [CrossRef]

79. Burgos, E.; Montefalcone, M.; Ferrari, M.; Paoli, C.; Vassallo, P.; Morri, C.; Bianchi, C.N. Ecosystem functions and economic wealth: Trajectories of change in seagrass meadows. J. Clean. Prod. 2017, 168, 1108-1119. [CrossRef]

80. Marbà, N.; Díaz-Almela, E.; Duarte, C.M. Mediterranean seagrass (Posidonia oceanica) loss between 1842 and 2009 . Biol. Conserv. 2014, 176, 183-190. [CrossRef]

81. Bernard, G.; Boudouresque, C.F.; Picon, P. Long term changes in Zostera meadows in the Berre lagoon (Provence, Mediterranean Sea). Estuar. Coast. Shelf Sci. 2007, 73, 617-629. [CrossRef]

82. Bernard, G.; Bonhomme, P.; Boudouresque, C.F. Recovery of the seagrass Zostera marina in a disturbed Mediterranean lagoon (Etang de Berre, Bouches-du-Rhône, Southern France). Hydrobiologia 2005, 539, 157-161. [CrossRef]

83. Plus, M.; Chapelle, A.; Lazure, P.; Auby, I.; Levavasseur, G.; Verlaque, M.; Belsher, T.; Deslous-Paoli, J.M.; Zaldívar, J.M.; Murray, C.N. Modelling of oxygen and nitrogen cycling as a function of macrophyte community in the Thau lagoon. Cont. Shelf Res. 2003, 23, 1877-1898. [CrossRef]

84. Rismondo, A.; Curiel, D.; Scarton, F.; Mion, D.; Caniglia, G. A new seagrass map for the Venice Lagoon. In Proceedings of the Sixth International Conference on the Mediterranean Coastal Environment, Ravenna, Italy, 7-11 October 2003; Middle East Technical University Publications: Ankara, Turkey, 2003; pp. 843-852.

85. Sfriso, A.; Buosi, A.; Tomio, Y.; Juhmani, A.-S.; Facca, C.; Sfriso, A.A.; Franzoi, P.; Scapin, L.; Bonometto, A.; Ponis, E.; et al. Aquatic angiosperm transplantation: A tool for environmental management and restoring in transitional water systems. Water 2019, 11, 2135. [CrossRef]

86. Shili, A.; Trabelsi, E.B.; Ben Maiz, N. Benthic macrophyte communities in the Ghar El Melh Lagoon (North Tunisia). J. Coast. Conserv. 2002, 8, 135-140. [CrossRef] 
87. Pergent-Martini, C. Protection des Habitats D’herbiers de Phanérogames Marines de Méditerranée. Les Etudes D'impacts en Milieu Marin; Centre d'Activités Régionales Aires Spécialement Protégées (Plan d'Action Pour La Méditerranée) Publications: Tunis, Tunisia, 2000; p. 66.

88. Zaouali, J. Flore et faune benthiques de deux lagunes tunisiennes: Le lac de Bizerte, Tunisie septentrionale, et la mer de Bou Grara, Tunisie méridionale. Bull. Off. Natl. Pêche Tunis. 1980, 4, 169-200.

89. Barrajón, A.; Moreno, D.; Pérez Lloréns, J.L. Las praderas de Zostera marina. Distribución en Andalucía. In Praderas y Bosques Marinos de Andalucía; Luque, A.A., Templado, J., Eds.; Consejería de Medio Ambiente: Sevilla, Spain, 2004; p. 336.

90. Pergent, G.; Bazairi, H.; Bianchi, C.N.; Boudouresque, C.F.; Buia, M.C.; Clabaut, P.; Harmelin-Vivien, M.; Mateo, M.A.; Montefalcone, M.; Morri, C.; et al. Mediterranean Seagrass Meadows: Resilience and Contribution to Climate Change Mitigation. A Short Summary; IUCN Publications: Gland, Switzerland; Málaga, Spain, 2012; p. 40.

91. Cunha, A.H.; Assis, J.F.; Serrão, E.A. Seagrasses in Portugal: A most endangered marine habitat. Aquat. Bot. 2013, 104, 193-203. [CrossRef]

92. Grillas, P.; Charpentier, A.; Auby, I.; Lescuyer, F.; Coulet, E. Spatial dynamics of Zostera noltii over a 5-year period of fluctuating salinity in the Vaccarès Lagoon, France. Biol. Mar. Mediterr. 2000, 7, 377-380.

93. Charpentier, A.; Grillas, P.; Lescuyer, F.; Coulet, E.; Auby, I. Spatio-temporal dynamics of a Zostera noltii dominated community over a period of fluctuating salinity in a shallow lagoon, Southern France. Estuar. Coast. Shelf Sci. 2005, 64, 307-315. [CrossRef]

94. Petit, G.; Aleem, A.A. Caractéristiques et évolution de la végétation d'un étang des Pyrénées-Orientales. C.R. Hebd. Séances Acad. Sci. 1952, 235, 632-634.

95. Hervé, P.; Bruslé, J. L'étang de Canet-Saint-Nazaire (P.O.). Ecologie générale et ichtyofaune. Life Environ. 1981, 31 , 17-23.

96. Scarton, F.; Curiel, D.; Rismondo, A. Aspetti della dinamica temporal di praterie a Fanerogame marine in laguna di Venezia. Lav. Soc. Venez. Sci. Nat. 1995, 20, 95-102.

97. Meinesz, A.; Javel, F.; Cottalorda, J.M.; Thibaut, T. Disparition des Phanérogames Marines Cymodocea nodosa et Nanozostera Noltii Dans la Lagune de L'anse de Port-Cros (Var) et Transplantation Expérimentale de C. nodosa. Rapport Laboratoire Environnement Marin Littoral-Université de Nice-Sophia Antipolis; LEML-UNSA Publications: Nice, France, 2005; p. 7.

98. Haritonidis, S.; Diapoulis, A.; Nikolaidis, G. First results on the localisation of the herbiers of marine phanerogams in the Gulf of Thermaikos. Posidonia Newsl. 1990, 3, 11-18.

99. Ben Maiz, N.; Shili, A. Les peuplements phytobenthiques du Lac Nord de Tunis de 1926 à 2006. In Proceedings of the 3rd Mediterranean Symposium on Marine Vegetation, Marseille, France, 27-29 March 2007; RAC/SPA Publications: Tunis, Tunisia, 2007; pp. 247-249.

100. Pérez-Ruzafa, A.; Ros, J.; Marcos, C.; Ballester, R.; Pérez-Ruzafa, I.M. Distribution and biomass of the macrophyte beds in a hypersaline coastal lagoon (the Mar Menor, SE Spain), and its recent evolution following major environmental changes. In Second International Workshop on Posidonia Beds; Boudouresque, C.F., Fresi, E., Gravez, V., Eds.; GIS Posidonie Publications: Marseille, France, 1989; pp. 49-62.

101. Pérez-Ruzafa, A.; García-Charton, J.A.; Barcala, E.; Marcos, D. Changes in benthic fish assemblages as a consequence of coastal works in a coastal lagoon: The Mar Menor (Spain, Western Mediterranean). Mar. Pollut. Bull. 2005, 53, 107-120. [CrossRef]

102. Deguen, F; Molinier, R. Études écologiques et biocénotiques dans la baie du Brusc (Var). Fascicule 1. Les sols phanérogamiques de la formation lagunaire du Brusc. Bull. Inst. Oceanogr. 1961, 58, 1-50.

103. Francour, P. La lagune du Brusc. Synthèse Bibliographique et État Actuel; Ministère de l'Environnement and GIS Posidonie Publications: Marseille, France, 1987; p. 51.

104. Bernard, G.; Bonhomme, P.; Boudouresque, C.F. Relevé des Herbiers de Magnoliophytes Marines Dans la Lagune du Brusc (Commune de Six-Fours-les-Plages, Var). Dans le Cadre du Projet de Réorganisation des Mouillages Forains Dans la Lagune; GIS Posidonie Publications: Marseille, France, 2004; p. 24.

105. Rouanet, É.; Bonnefont, J.L.; Durand, R. Site Natura 2000 FR 9302001 'Lagune du Brusc'—Document D'objectifs—Tome 1: Diagnostics Ecologiques et Socioéconomiques, Enjeux et Objectifs de Conservation Hiérarchisés; Institut Océanographique Paul Ricard Publications: Marseille, France, 2009; p. 102.

106. Couvray, S.; Simide, R.; Kirchhofer, D.; Vion, A.; Bonnefont, J.L. Projet SAR-LAB. Site Atelier de Restauration Ecologique Lagune du Brusc. Rapport Intermédiaire; Phase 2017-2018; Institut Océanographique Paul Ricard Publications: Six-Fours-la-Plage, France, $2020 ;$ p. 140.

107. Simide, R.; Abello, C.; Marsac, R.; Couvray, S. A unique feature of lagoon along French Mediterranean coast. In Proceedings of the Gecomars 2020 - International Workshop on Ecosystem Based Management, Marseille, France, 4-5 February 2020.

108. Montefalcone, M.; Albertelli, G.; Morri, C.; Bianchi, C.N. Urban seagrass: Status of Posidonia oceanica facing Genoa city waterfront (Italy) and implications for management. Mar. Pollut. Bull. 2007, 54, 206-213. [CrossRef]

109. Montefalcone, M.; Morri, C.; Peirano, A.; Albertelli, G.; Bianchi, C.N. Substitution and phase shift within the Posidonia oceanica seagrass meadows of NW Mediterranean Sea. Estuar. Coast. Shelf Sci. 2007, 75, 63-71. [CrossRef]

110. Oprandi, A.; Montefalcone, M.; Vacchi, M.; Coppo, S.; Diviacco, G.; Morri, C.; Ferrari, M.; Bianchi, C.N. Combining modelling and historical data to define the status of Posidonia oceanica meadows. In Proceedings of the 5th Mediterranean Symposium on Marine Vegetation, Portorož, Slovenia, 27-28 October 2014; Langar, H., Bouafif, C., Ouerghi, A., Eds.; RAC/SPA Publications: Tunis, Tunisia, 2014; pp. 119-124.

111. den Hartog, C.; Priest, L. A profound view and discourse on the typification and status of three confused taxa: Ruppia maritima, R. spiralis and R. cirrhosa. Bot. Mar. 2020, 63, 229-239. [CrossRef] 
112. Mars, P. Recherches sur quelques étangs du litoral méditerranéen français et sur leurs faunes malacologiques. Life Environ. 1966, 20,1-359.

113. Chomerat, N. Patrons de Réponse du Phytoplancton à La Variabilité des Facteurs Abiotiques Dans un Etang Méditerranéen Hypereutrophe: Succès Ecologique de Planktothrix agardhii (Gom.) Anagn. \& Kom. (Cyanoprocaryote) Dans un Ecosystème Saumâtre. Ph.D. Thesis, Aix-Marseille University, Marseille, France, 2005.

114. Acunto, S.; Maltagliati, F.; Rindi, F.; Rossi, F.; Cinelli, F. Osservazioni su Una Prateria di Halophila stipulacea (Forssk.) Aschers. (Hydrocharitaceae) nel Mar Tirreno Meridionale. Atti Soc. Tosc. Sci. Nat. Mem. Ser. B 1995, 102, 19-22.

115. Gambi, M.C.; Barbieri, F.; Bianchi, C.N. New record of the alien seagrass Halophila stipulacea (Hydrocharitaceae) in the western Mediterranean: A further clue to changing Mediterranean Sea biogeography. Mar. Biodivers. Rec. 2009, 2, 1-7. [CrossRef]

116. Calvo, S.; Tomasello, A.; Di Maida, G.; Pirrotta, M.; Buia, M.C.; Cinelli, F.; Cormaci, M.; Furnari, G.; Giaccone, G.; Luzzu, F.; et al. Seagrasses along the Sicilian coasts. Chem. Ecol. 2010, 26, 249-266. [CrossRef]

117. Sghaier, Y.R.; Zakhama-Sraieb, R.; Benamer, I.; Charfi-Cheikhrouha, F. Occurrence of the seagrass Halophila stipulacea (Hydrocharitaceae) in the southern Mediterranean Sea. Bot. Mar. 2011, 54, 575-582. [CrossRef]

118. Gambi, M.C.; Gaglioti, M.; Barbieri, F. Sometimes they come back: The re-colonization of the alien seagrass Halophila stipulacea (Forsskål) Ascherson, 1867 (Hydrocharitaceae) in the Palinuro Harbor (Tyrrenian Sea, Italy). BioInvasions Rec. 2018, 7, $215-221$. [CrossRef]

119. Montefalcone, M.; Bianchi, C.N.; Morri, C.; Peirano, A.; Albertelli, G. Lower limit typology and functioning of six Posidonia oceanica meadows in the Ligurian Sea (NW Mediterranean). Biol. Mar. Mediterr. 2006, 13, 262-266.

120. Meinesz, A.; Astier, J.M.; Bodoy, A.; Cristiani, G.; Lefèvre, J.R. Impact de l'aménagement du domaine maritime sur l'étage infralittoral des Bouches-du-Rhône (France, Méditerranée occidentale). Life Environ. 1982, 32, 115-124.

121. Meinesz, A.; Lefèvre, J.R.; Astier, J.M. Impact of coastal development on the infralittoral zone along the southern Mediterranean shore of continental France. Mar. Pollut. Bull. 1991, 23, 343-347. [CrossRef]

122. Ganteaume, A.; Bonhomme, P.; Emery, E.; Hervé, G.; Boudouresque, C.F. Impact sur la prairie à Posidonia oceanica de l'amarrage des bateaux de croisière, au large du port de Porquerolles (Provence, France, Méditerranée). Sci. Rep. Port-Cros Natl. Park 2005, 21, 163-173.

123. Andromede Oceanologie. Le Projet REPIC, Début D'une Politique de Restauration des Herbiers Sous-Marins à Posidonies en France? 2019. Available online: https://medtrix.fr/le-projet-repic-debut-dune-politique-de-restauration-des-herbiers-sousmarins-a-posidonie-en-france/ (accessed on 15 December 2020).

124. Bedini, R.; Bedini, M.; Salvadori, E. A new transplanting method of Posidonia oceanica (Linnaeus) Delile, 1813 plants. In Monitoring of Mediterranean Coastal Areas. Problems and Measurement Techniques; Bonora, L., Carboni, D., de Vicenzi, M., Eds.; Firenze University Press: Florence, Italy, 2020; pp. 492-500.

125. Cunha, A.H.; Marbá, N.N.; van Katwijk, M.M.; Pickerell, C.; Henriques, M.; Bernard, G.; Ferreira, M.A.; Garcia, S.; Garmendia, J.M.; Manent, P. Changing paradigms in seagrass restoration. Restor. Ecol. 2012, 20, 427-430. [CrossRef]

126. Caye, G. Sur la Morphogénèse et le Cycle Végétatif de Posidonia oceanica (L.) Delile. Ph.D. Thesis, Aix-Marseille University, Marseille, France, 1980; p. 121.

127. Boudouresque, C.F.; Meinesz, A. Découverte de l'herbier de Posidonie. Parc national de Port-Cros. Cahier 1982, 4, 1-79.

128. Boudouresque, C.F.; Jeudy de Grissac, A.; Meinesz, A. Relations entre la sédimentation et l'allongement des rhizomes orthotropes de Posidonia oceanica dans la baie d'Elbu (Corse). In International Workshop on Posidonia Oceanica Beds, Porquerolles, France, 12-15 October 1983; Boudouresque, C.F., Jeudy de Grissac, A., Ollivier, J., Eds.; GIS Posidonie Publications: Marseille, France, 1984; Volume 1, pp. 185-191.

129. Mossé, R.A. Recherches lépidochronologiques sur Posidonia oceanica: Rhizomes plagiotropes et orthotropes des herbiers profonds de Port-Cros (Mediterranée, France). Trav. Sci. Parc Natl. Port-Cros 1984, 10, 87-107.

130. González-Correa, J.M.; Bayle-Sempere, J.T.; Sánchez-Lizaso, J.L.; Valle, C.; Sánchez-Jerez, P.; Ruiz, J.M. Recovery of deep Posidonia oceanica meadows degraded by trawling. J. Exp. Mar. Biol. Ecol. 2005, 320, 65-76. [CrossRef]

131. Calvo, S.; Lovison, G.; Pirrotta, M.; Di Maida, G.; Tomasello, A.; Sciandra, M. Modelling the relationship between sexual reproduction and rhizome growth in Posidonia oceanica (L.) Delile. Mar. Ecol. 2006, 27, 361-371. [CrossRef]

132. Tomasello, A.; Sciandra, M.; Muggeo, V.M.R.; Pirrotta, M.; Di Maida, G.; Calvo, S. Reference growth charts for Posidonia oceanica seagrass: An effective tool for assessing growth performance by age and depth. Ecol. Indic. 2016, 69, 50-58. [CrossRef]

133. Meinesz, A.; Lefèvre, J.R. Régénération d'un herbier à Posidonia oceanica quarante années après sa destruction par une bombe dans la rade de Villefranche (Alpes Maritimes). In International Workshop on Posidonia oceanica Beds, Porquerolles, France, 12-15 October 1983; Boudouresque, C.F., Jeudy de Grissac, A., Olivier, J., Eds.; GIS Posidonie Publications: Marseille, France, 1984; Volume 1, pp. 39-44.

134. Marbà, N.; Duarte, C.M. Rhizome elongation and seagrass clonal growth. Mar. Ecol. Prog. Ser. 1998, 174, 269-280. [CrossRef]

135. Di Carlo, G.; Badalamenti, F.; Jensen, A.C.; Koch, E.W.; Riggio, S. Colonisation process of vegetative fragments of Posidonia oceanica (L.) Delile on rubble mounds. Mar. Biol. 2005, 147, 1261-1270. [CrossRef]

136. Giraud, G. Recensement des floraisons de Posidonia oceanica (L.) Delile en Méditerranée. Rapp. Comm. Int. Mer Mediterr. 1977, 24, 126-130.

137. Thélin, I.; Boudouresque, C.F. Posidonia oceanica flowering and fruiting: Recent data from an international inquiry. Posidonia Nezwsl. $1985,1,5-14$. 
138. Romero, J. Note sur la floraison de Posidonia oceanica (L.) Delile dans les îles Medas (Gerona, Espagne). Posidonia Nerwsl. 1989, 2 , $15-18$.

139. Balestri, E.; Piazzi, L.; Acunto, S.; Cinelli, F. Flowering and fruiting beds in Tuscany (Italy). In La Posidonia oceanica; Cinelli, F., Fresi, E., Lorenzi, C., Mucedola, A., Eds.; Revista Marittima Publications: Rome, Italy, 1995; Volume 12, pp. 25-30.

140. Balestri, E.; Cinelli, F. Sexual reproductive success in Posidonia oceanica. Aquat. Bot. 2003, 75, 21-32. [CrossRef]

141. Diaz Almela, E.; Marbà, N.; Álvarez, E.; Balestri, E.; Ruiz-Fernández, J.M.; Duarte, C.M. Patterns of seagrass (Posidonia oceanica) flowering in the Western Mediterranean. Mar. Biol. 2006, 148, 723-742. [CrossRef]

142. Diaz-Almela, E.; Marbà, N.; Duarte, C.M. Consequences of Mediterranean warming events in seagrass (Posidonia oceania) flowering records. Glob. Chang. Biol. 2007, 13, 224-235. [CrossRef]

143. Pergent, G. Recherches Lépidochronologiques Chez Posidonia oceanica (Potamogetonaceae). Fluctuations des Paramètres Anatomiques et Morphologiques des Écailles des Rhizomes. Ph.D. Thesis, Aix-Marseille University, Marseille, France, $1987 ;$ p. 853.

144. Pergent, G.; Ben Maiz, N.; Boudouresque, C.F.; Meinesz, A. The flowering of Posidonia oceanica over the past fifty years: A lepidochronological study. In International Workshop on Posidonia Beds; Boudouresque, C.F., Meinesz, A., Fresi, E., Gravez, V., Eds.; GIS Posidonie Publications: Marseille, France, 1989; Volume 2, pp. 69-76.

145. Pergent, G.; Pergent-Martini, C. Some applications of lepidochronological analysis in the seagrass Posidonia oceanica. Bot. Mar. 1990, 33, 299-310. [CrossRef]

146. Mateo, M.A.; Romero, J.; Pérez, M.; Littler, M.M.; Littler, D.S. Dynamics of millenary organic deposits resulting from the growth of the Mediterranean seagrass Posidonia oceanica. Estuar. Coast. Shelf Sci. 1997, 44, 103-110. [CrossRef]

147. Sandmeier, M.; Caye, G.; Molenaar, H. Seed enzyme polymorphism and autogamy of the seagrass Posidonia oceanica from the western Mediterranean. Bot. Mar. 1999, 42, 359-366. [CrossRef]

148. Piazzi, L.; Balestri, E.; Cinelli, E. Grazing of inflorescences of the seagrass Posidonia oceanica (L.) Delile. Bot. Mar. 2000, 43, 561-584. [CrossRef]

149. Sánchez-Lizaso, J.L. Las praderas de FanerÓgamas marinas. ReproducciÓn sexual: FloraciÓn, fructificaciÓn y germinaciÓn. Estructura genética de las praderas. In Praderas y Bosques Marinos de Andalucía; Luque, A.A., Templado, J., Eds.; Consejería de Medio Ambiente, Junta de Andalucía Publications: Sevilla, Spain, 2004; pp. 67-69.

150. Vergés, A.; Becerro, M.A.; Alcoverro, T.; Romero, J. Variation in multiple traits of vegetative and reproductive seagrass tissues influences plant-herbivore interactions. Oecologia 2007, 151, 675-686. [CrossRef]

151. Ferrari, B.; Raventos, N.; Planes, S. Assessing effects of fishing prohibition on Posidonia oceanica seagrass meadows in the Marine Natural Reserve of Cerbère-Banyuls. Aquat. Bot. 2008, 88, 295-302. [CrossRef]

152. Janzen, D.H. Seed predation by animals. Annu. Rev. Ecol. Syst. 1971, 2, 465-492. [CrossRef]

153. Curran, L.M.; Leighton, M. Vertebrate responses to spatiotemporal variation in seed production of mast-fruiting Dipterocarpaceae. Ecol. Monogr. 2000, 70, 101-128. [CrossRef]

154. Richardson, S.J.; Allen, R.B.; Whitehead, D.; Carswell, F.E.; Ruscoe, W.A.; Platt, K.H. Climate and net carbon availability determine temporal patterns of seed production by Nothofagus. Ecology 2005, 86, 972-981. [CrossRef]

155. Pergent-Martini, C. Impact D'un Rejet D'eaux Usées Urbaines sur L'herbier à Posidonia oceanica, Avant et Après La Mise en Service D'une Station D'épuration. Ph.D. Thesis, Pascal Paoli University of Corsica, Corsica, France, 1994; p. 191.

156. Pergent-Martini, C.; Pergent, G. Spatio-temporal dynamics of Posidonia oceanica beds near a sewage outfall (MediterraneanFrance). In Seagrass Biology: Proceedings of an International Workshop, Rottnest Island, Australia, 25-29 January 1996; Kuo, J., Phillips, R.C., Walker, D.I., Kirkman, H., Eds.; Faculty of Sciences, the University of Western Australia Publications: Nedlands, Australia, 1996; pp. 299-306.

157. Pergent-Martini, C.; Pasqualini, V. Seagrass population dynamics before and after the setting up of a wastewater treatment plant. Biol. Mar. Mediterr. 2000, 7, 405-408.

158. Gravez, V.; Gélin, A.; Charbonnel, E.; Francour, P.; Abellard, O.; Remonnay, L. Surveillance de L'herbier de Posidonie de La Baie du Prado (Marseille)—Suivi 1995; Ville de Marseille and GIS Posidonie Publications: Marseille, France, 1995; p. 56.

159. Bernard, G.; Cadiou, G.; Escoffier, B.; Le Direach, L.; Bonhomme, P.; Charbonnel, E. Surveillance de L'herbier à Posidonia oceanica du Golfe de Giens (Var, France). Seconde Phase, Premier Suivi, Syndicat Intercommunal Hyères-Carqueiranne Pour L'assainissement de La Baie de Giens and GIS Posidonie; GIS Posidonie Publications: Marseille, France, 2000; p. 61.

160. Ragonese, S.; Rizzo, A. Dove cresce la Posidonia? Notizario SIBM 2013, 64, 49-50.

161. Cotugno, M.; Lorenti, M.; Scipione, M.B.; Buia, M.C. Spontaneous Posidonia oceanica recovery. In Proceedings of the Fourteenth International MEDCOAST Congress on Coastal and Marine Sciences Engineering, Management and Conservation, Marmaris, Turkey, 22-26 October 2019; pp. 287-296.

162. Di Carlo, G.; Badalamenti, F.; Terlizzi, A. Recruitment of Posidonia oceanica on rubble mounts: Substratum effects on biomass partitioning and leaf morphology. Biol. Mar. Mediterr. 2006, 13, 210-214.

163. Di Carlo, G.; Badalamenti, F.; Terlizzi, A. Recruitment of Posidonia oceanica on rubble mounts: Substratum effects on biomass partitioning and leaf morphology. Aquat. Bot. 2007, 87, 97-103. [CrossRef]

164. Badalamenti, F.; Alagna, A.; D'Anna, G.; Terlizzi, A.; Di Carlo, G. The impact of dredge-fill on Posidonia oceanica seagrass meadows: Regression and patterns of recovery. Mar. Pollut. Bull. 2011, 62, 483-489. [CrossRef]

165. Gambi, M.C.; Guidetti, P. Morphological observations on seedlings of Posidonia oceanica (L) Delile germinated in situ. Biol. Mar. Mediterr. 1998, 5, 549-552. 
166. Buia, M.C.; Piraino, S. Record of Posidonia oceanica (L.) Delile seedlings in the Egadi Islands (Sicily, Italy). Posidonia Newsl. 1989, 2, 19-22.

167. Buia, M.C.; Mazzella, L. Reproductive phenology of the Mediterranean seagrasses Posidonia oceanica (L.) Delile, Cymodocea nodosa (Ucria) Aschers., and Zostera noltii Hornm. Aquat. Bot. 1991, 40, 343-362. [CrossRef]

168. Acunto, S.; Piazzi, L.; Balestri, E.; Cinelli, F. Segnalazioni Di Fioriture Di Posidonia Oceanica (L.) Delile Lungo Le Coste Toscane. Biol. Mar. Mediterr. 1996, 3, 437-438.

169. Gambi, M.C.; Buia, M.C.; Mazzella, L. Record of a diffuse germination of Posidonia oceanica (L.) Delile in the central Adriatic Sea (Croatia). Biol. Mar. Mediterr. 1996, 3, 467-470.

170. Balestri, E.; Piazzi, L.; Cinelli, F. Survival and growth of transplanted and natural seedlings of Posidonia oceanica (L.) Delile in a damaged coastal area. J. Exp. Mar. Biol. Ecol. 1998, 228, 209-225. [CrossRef]

171. Piazzi, L.; Acunto, S.; Balestri, E.; Cinelli, F. Osservazioni preliminari sulla germinazione di semi e sviluppo in situ di piantine di Posidonia oceanica (L.) Delile. Inf. Bot. Ital. 1996, 28, 61-66.

172. Alagna, A.; Fernandez, T.V.; Di Carlo, G.; Terlizzi, A.; Badalamenti, F. Influence of substrate type and algal cover on seedlings recruitment and growth performances of the Mediterranean seagrass Posidonia oceanica. In Proceedings of the 4th Mediterranean Symposium on Marine Vegetation, Yasmine-Hammamet, Tunisia, 2-4 December 2010; El Asmi, S., Langar, H., Belkacem, W., Eds.; RAC/SPA Publications: Tunis, Tunisia, 2010; pp. 149-150.

173. Alagna, A.; Fernandez, T.V.; Terlizzi, A.; Badalamenti, F. Influence of microhabitat on seedling survival and growth of the Mediterranean seagrass Posidonia oceanica (L.) Delile. Estuar. Coast. Shelf Sci. 2013, 119, 119-125. [CrossRef]

174. Badalamenti, F.; Alagna, A.; Fici, S. Evidences of adaptative traits to rocky substrates undermine paradigm of habitat preference of the Mediterranean seagrass Posidonia oceanica. Sci. Rep. 2015, 5, srep08804. [CrossRef]

175. Alagna, A.; Vega Fernández, T.; D’Anna, G.; Magliola, C.; Mazzola, S.; Badalamenti, F. Assessing Posidonia oceanica seedling substrate preference: An experimental determination of seedling anchorage success in rocky vs. sandy substrates. PLoS ONE 2015, 10, e125321. [CrossRef]

176. Balestri, E.; Vallerini, F.; Lardicci, C. Recruitment and patch establishment by seed in the seagrass Posidonia oceanica: Importance and conservation implications. Front. Plant Sci. 2017, 8, 1-12. [CrossRef]

177. Procaccini, G.; Mazzella, L. Genetic variability and reproduction in two Mediterranean seagrasses. In Seagrass biology: Proceedings of an International Workshop, Rottnest Island, Australia, 25-29 January 1996; Kuo, J., Phillips, R.C., Walker, D.I., Kirkman, H., Eds.; The University of Western Australia Publications: Perth, Australia, 1996; pp. 85-92.

178. Procaccini, G. Microsatellite DNA polymorphism in Posidonia oceanica (L.) Delile. Biol. Mar. Mediterr. 1997, 4, 436-439.

179. Micheli, C.; Cupido, R.; Lombardi, C.; Belmonte, A.; Peirano, A. Changes in genetic structure of Posidonia oceanica at Monterosso al Mare (Ligurian Sea) and its resilience over a decade (1998-2009). Environ. Manag. 2012, 50, 598-606. [CrossRef]

180. Micheli, C.; D'esposito, D.; Belmonte, A.; Peirano, A.; Valiante, L.M.; Procaccini, G. Genetic diversity and structure in two protected Posidonia oceanica meadows. Mar. Environ. Res. 2015, 109, 124-131. [CrossRef]

181. Gnisci, V.; de Martiis, S.C.; Belmonte, A.; Micheli, C.; Piermattei, V.; Bonamano, S.; Marcelli, M. Assessment of the ecological structure of Posidonia oceanica (L.) Delile on the northern coast of Lazio, Italy (central Tyrrhenian, Mediterranean). Ital. Bot. 2020, 9, 1-19. [CrossRef]

182. IUCN. Translocation of Living Organisms; IUCN: Gland, Switzerland, 1987; p. 20.

183. Boudouresque, C.F. La restauration des écosystèmes à phanérogames marines. In Restauration des Ecosystèmes Côtiers; Drévès, L., Chaussepied, M., Eds.; IFREMER: Paris, France, 2001; Volume 29, pp. 65-85.

184. Elliott, M.; Burdon, D.; Hemingway, K.L.; Apitz, S.E. Estuarine, coastal and marine ecosystem restoration: Confusing management and science-A revision of concepts. Estuar. Coast. Shelf Sci. 2007, 74, 349-366. [CrossRef]

185. Meinesz, A.; Caye, G.; Loquès, F.; Macaux, S. Analyse bibliographique sur la culture des Phanérogames marines. Posidonia Newsl. 1990, 3, 1-67.

186. Cinelli, F. La riforestazione quale mezzo di ripristino e di controllo per les praterie di fanerogame marine. In Parchi Marini del Mediterraneo. Probleme e Perspective. Atti del 2 Convegno Internazionale. San Teodoro; Icimar: Sardegna, Italy, $1991 ;$ pp. 78-82.

187. Addy, C.E. Eelgrass planting guide. Md. Conserv. 1947, 24, 16-17.

188. Thorhaug, A. The flowering and fruiting of restored Thalassia beds: A preliminary note. Aquat. Bot. 1979, 6, 189-192. [CrossRef]

189. Fonseca, M.S.; Kenworthy, W.J.; Thayer, G.W. A Low-Cost Planting Technique for Eelgrass (Zostera marina L.); National marine Fisheries Service, Southeast Fisheries Center, Beaufort Laboratory: Beaufort, NC, USA, 1982; p. 15.

190. Fonseca, M.S.; Kenworthy, W.J.; Thayer, G.W. A low cost transplanting procedure for sediment stabilization and habitat development using eelgrass (Zostera marina). Wet Lands 1982, 2, 138-151. [CrossRef]

191. Bastyan, G.R.; Cambridge, M.L. Transplantation as a method for restoring the seagrass Posidonia australis. Estuar. Coast. Shelf Sci. 2008, 79, 289-299. [CrossRef]

192. Addy, C.E. Germination of eelgrass seeds. J. Wildl. Manag. 1947, 11, 279. [CrossRef]

193. van Katwijk, M.M.; Thorhaug, A.; Marbà, N.; Orth, R.J.; Duarte, C.M.; Kendrick, G.A.; Althuizen, I.H.J.; Balestri, E.; Bernard, G.; Cambridge, M.L.; et al. Global analysis of seagrass restoration: The importance of large-scale planting. J. Appl. Ecol. 2016, 53, 567-578. [CrossRef]

194. Carannante, F. Monitoraggio a Lungo Termine di Trapianti di Posidonia oceanica su Vasta Scala. Ph.D. Thesis, Università di Viterbo, Viterbo, Italy, 2011; p. 175. 
195. Astruch, P.; Rouanet, É.; Boudouresque, C.F. Étude sur la Thématique de la Réintroduction D'espèces Dans le Milieu Naturel. Volet Scientifique. Contrat Direction de L'ENVIRONNEMENT de La Principauté de Monaco and GIS Posidonie; GIS Posidonie Publications: Marseille, France, 2016; p. 92.

196. Maggi, P. Le problème de la disparition des herbiers à posidonies dans le golfe de Giens (Var). Sci. Pêche 1973, $221,7-20$.

197. Cooper, G. Jardinier de la Mer. Association-Fondation, G. Cooper pour la reconquête des milieux naturels détruits. Cahier 1976, 1 , $1-57$.

198. Cooper, G. Réimplantation de Posidonia oceanica. Protection des implants. Bull. Ecol. 1982, 13, 65-73.

199. Giaccone, G.; Calvo, S. Restaurazione del manto vegetale mediante trapianto di Posidonia oceanica (Linneo) Delile. Risultati preliminari. Mem. Biol. Mar. Oceanogr. 1980, 10, 207-211.

200. Eugène, C.; Sougy-Peuriere, A.; Augier, H.; Cabrerizo, A.; Harmand, J.M.; Sougy, M. Réhabilitation des Fonds Marins de la Réserve Marine de Monaco. Compte-Rendu du Premier Suivi (Effectué en Septembre 1993) Sur la Réimplantation par Bouturage (Réalisée en Juin 1993) de 2990 Tiges de Posidonies; CERIMER: Marseille, France, 1993; p. 29.

201. Sougy, A. Les posidonies face aux attaques de la mer. Mer Littoral 1996, 15, 45-47.

202. Tomasello, A.; Pirrotta, M.; Calvo, S. Construction underwater landscape by using Posidonia oceanica transplanting combined with innovative artificial reefs. In Proceedings of the 6th Mediterranean Symposium on Marine Vegetation, Antalya, Turkey, 14-15 January 2019; Langar, H., Ouerghi, A., Eds.; RAC/SPA Publications: Tunis, Tunisia, 2019; pp. 92-97.

203. Molenaar, H.; Meinesz, A. Vegetative reproduction in Posidonia oceanica. II. Effects of depth changes on transplanted orthotropic shoots. Mar. Ecol. 1992, 13, 175-185. [CrossRef]

204. Molenaar, H.; Meinesz, A.; Caye, G. Vegetative reproduction in Posidonia oceanica. Survival and development in different morphological types of transplanted cuttings. Bot. Mar. 1993, 36, 481-488. [CrossRef]

205. Piazzi, L.; Cinelli, F. Restoration of the littoral sea bottom by means of transplantation of cuttings and sprouts. In Posidonia oceanica, a Contribution to the Preservation of a Major Mediterranean Marine Ecosystem; Cinelli, F., Fresi, E., Lorenzi, C., Mucedola, A., Eds.; Revista Marittima: Rome, Italy, 1995; pp. 69-71.

206. Piazzi, L.; Balestri, E.; Magri, M.; Cinelli, F. Experimental transplanting of Posidonia oceanica (L.) Delile into a disturbed habitat in the Mediterranean Sea. Bot. Mar. 1998, 41, 593-601. [CrossRef]

207. Piazzi, L.; Balestri, E.; Balata, D.; Cinelli, F. Pilot transplanting experiment of Posidonia oceanica (L.) Delile to restore a damaged coastal area in the Mediterranean Sea. Biol. Mar. Mediterr. 2000, 7, 409-411.

208. Vangeluwe, D.; Lepoint, G.; Bouquegneau, J.M.; Gobert, S. Effet de la transplantation sur les pousses de Posidonia oceanica (L.) Delile. Life Environ. 2004, 54, 223-230.

209. Gobert, S.; Lepoint, G.; Bouquegneau, J.M.; Vangeluwe, D.; Eisinger, M.; Paster, M.; Schuhmaker, H.; van Treeck, P. Restoration of seagrass meadows: Means and limitations. In Proceedings of the Seventh International Conference on the Mediterranean Coastal Environment, MEDCOAST 05, Kusadasi, Turkey, 7-11 October 2005; Ozhan, E., Ed.; MEDCOAST Secretariat, Middle East Technical University: Ankara, Turkey, 2005; pp. 1323-1334.

210. Vangeluwe, D. Effets de la Transplantation sur La Biométrie et La Dynamique des Nutriments, du Carbone et de La Chlorophylle de Posidonia oceanica (L.) Delile. Ph.D. Thesis, University of Liège, Liège, Belgium, 2006; p. 196.

211. Meinesz, A.; Cottalorda, J.M.; Molenaar, H. Bilan sur L'évolution des Boutures et Plantules de Posidonies, Provenant du Bassin Méditerranéen, Transplantées en 1988-1995 Dans le Parc National de Port-Cros "Le Posidonium"; Report Université Nice Sophia Antipolis and GIS Posidonie Publications: Marseille, France, 2013; p. 55.

212. Pirrotta, M.; Tomasello, A.; Scannavino, A.; Di Maida, G.; Luzzu, F.; Bellissimo, G.; Bellavia, C.; Costantini, C.; Orestano, C.; Sclafani, G.; et al. Transplantation assessment of degraded Posidonia oceanica habitats: Site selection and long-term monitoring. Mediterr. Mar. Sci. 2015, 16, 591-604. [CrossRef]

213. Larkum, A.W.D. Ecology of Botany Bay. I. Growth of Posidonia australis (Brown) Hook f. in Botany Bay and other bays of the Sidney Basin. Austr. J. Mar. Freshw. Res. 1976, 27, 117-127. [CrossRef]

214. Short, F.T.; Kopp, B.S.; Gaeckle, J.; Tamaki, H. Seagrass ecology and estuarine mitigation: A low-cost method for eelgrass restoration. Fish. Sci. 2002, 68, 1759-1762. [CrossRef]

215. Bovina, G. Conservazione e restauro delle praterie di Posidonia oceanica. In Il Ripristino Degli Ecosistemi Marino-Costieri e La Difesa Delle Coste Sabbiose Nelle Aree Protette; Onori, L., Ed.; ISPRA: Rome, Italy, 2009; pp. 309-339.

216. Acunto, S.; Piazzi, L.; Cinelli, F.L.; de Biasi, A.M.; Pacciardi, L.; Ceraudo, S.; Fersini, G. Transplantation of the Mediterranean seagrass Posidonia oceanica through naturalistic engineering techniques: Value, weakness and further improvements. PeerJ Prepr. 2015, 3, e1051v1. [CrossRef]

217. Alagna, A.; D'Anna, G.; Musco, L.; Fernandez, T.V.; Gresta, M.; Pierozzi, N.; Badalamenti, F. Taking advantage of seagrass recovery potential to develop novel and effective meadow rehabilitation methods. Mar. Pollut. Bull. 2019, 149, 1-12. [CrossRef]

218. Alagna, A.; D'Anna, G.; Musco, L.; Fernandez, T.V.; Gresta, M.; Pierozzi, N.; Badalamenti, F. Reply to "Letter to the editor regarding the article 'Taking advantage of seagrass recovery potential to develop novel and effective meadow rehabilitation methods' by Alagna et al., published in Marine Pollution Bulletin, 149: 2019 (110578)" by Calvo et al. Marine Pollution Bulletin, 158: 2020 (111395). Mar. Pollut. Bull. 2020, 161, 1-8.

219. Kenworthy, W.J.; Fonseca, M.S.; Homziak, J.; Thayer, G.W. Development of a transplanted seagrass (Zostera marina L) meadow in Back Sound, Carteret county, North Carolina. In Proceedings of the Seventh Annual Conference on the Restoration and Creation of Wetlands, Tampa, FL, USA, 16-17 May 1980; pp. 175-193. 
220. Davis, R.C.; Short, F.T. Restoring eelgrass, Zostera marina L., habitat using a new transplanting technique: The horizontal rhizome method. Aquat. Bot. 1997, 59, 1-15. [CrossRef]

221. Molenaar, H. Étude de La Transplantation de Boutures de La Phanérogame Marine Posidonia oceanica (L.) Delile. Modélisation de L'architecture et du Mode de Croissance. Ph.D. Thesis, Université Nice Sophia Antipolis, Nice, France, $1992 ;$ p. 221.

222. Ward, E.A.; Meek, S.K.; Gordon, D.M.; Cameron, T.C.; Steer, M.D.; Smith, D.J.; Miliou, A.; Tsimpidis, T. The use of storm fragments and biodegradable replanting methods allows for a low-impact habitat restoration method of sragrass meadows, in the eastern Aegean Sea. Conserv. Evid. 2020, 17, 1-6.

223. Rismondo, A.; Curiel, D.; Solazzi, A.; Marzocchi, M.; Chiozzotto, E.; Scattolin, M. Sperimentazione di trapianto di fanerogame marine in Laguna di Venezia: 1992-1994. Proc. Ital. Soc. Ecol. 1995, 16, 699-701.

224. Scannavino, A.; Pirrotta, M.; Tomasello, A.; Di Maida, G.; Luzzu, F.; Bellavia, C.; Bellissimo, G.; Costantini, C.; Orestano, C.; Scalfani, G.; et al. Biodegradable anchor modular system for transplanting Posidonia oceanica cuttings. In Proceedings of the 5th Mediterranean Symposium on Marine Vegetation, Portorož, Slovenia, 27-28 October 2014; Langar, H., Bouafif, C., Ouerghi, A., Eds.; RAC/SPA Publications: Tunis, Tunisia, 2014; pp. 236-237.

225. Fonseca, M.S.; Kenworthy, W.J.; Homziak, J.; Thayer, G.W. Transplanting of eelgrass and shoalgrass as a potential means of economically mitigating a recent loss of habitat. In Proceedings of the Sixth Annual Conference on Wetland Restoration and Creation, Tampa, FL, USA, 19 May 1979; Cole, D.P., Ed.; Environmental Studies Center, and Tampa Port Authority: Tampa, FL, USA, 1979; pp. 279-326.

226. Phillips, R.C. Planting guidelines for seagrasses. Coast. Eng. Tech. 1980, 80, 1-28.

227. Phillips, R.C. Responses of transplanted and indigenous Thalassia testudinum Banks ex König and Halodule wrightii Aschers. to sediment loading and cold stress. Contrib. Mar. Sci. 1980, 23, 79-87.

228. de La Rosa, M.R.; García, N.; Zarranz, M.; Manent, P.; Domínguez, R.; Grimón, M.; Louzara, G.; González, N. Preliminary results of experimental evaluation about different methods of transplanting Cymodocea nodosa in the Canary Islands. Biol. Mar. Mediterr. 2006, 13, 267-271.

229. Meinesz, A.; Verlaque, M. Note préliminaire concernant quelques expériences de repiquage de Caulerpa prolifera et de Zostera noltii dans la zone de rejet de l'effluent thermique de la centrale électrique de Martigues-Ponteau (golfe de Fos, France). Rapp. Comm. Int. Mer Mediterr. 1979, 25, 209-212.

230. Jeudy de Grissac, A. Essais d'implantations d'espèces végétales marines: Les espèces pionnières, les posidonies. In International Workshop on Posidonia oceanica Beds, Porquerolles, France, 12-15 October 1983; Boudouresque, C.F., Jeudy de Grissac, A., Olivier, J., Eds.; GIS Posidonie Publications: Marseille, France, 1984; Volume 1, pp. 431-436.

231. Bernard, G.; Morancy, R.; Jouvenel, J.Y.; Javel, F.; Meinesz, A. Étude des possibilités de restauration des herbiers de Zostera dans l'étang de Berre par des réimplantations expérimentales. In Les Actes des Rencontres LAGUN'R. Rencontres Scientifiques Autour de L'étang de Berre; Aix-en-Provence, GIPREB: Berre-l'Étang, France, 2013; pp. 345-359.

232. Curiel, D.; Rismondo, A.; Scarton, F.; Caniglia, G.; Marzocchi, M. Preliminary results on seagrass transplantation with Cymodocea nodosa and Zostera marina in Venice lagoon. G. Bot. Ital. 1995, 129, 138.

233. Faccioli, F. The morphological restoration of he Venice Lagoon. Quad. Trimest. Consorzio Venezia Nuova 1996, 4, 1-24.

234. da Ros, Z.; Corinaldesi, C.; Dell'Anno, A.; Gambi, C.; Torsani, F.; Danovaro, R. Restoration of Cymodocea nodosa seagrass meadows: Efficiency and ecological implications. Restor. Ecol. 2021, in press. [CrossRef]

235. Sánchez-Lizaso, J.L.; Fernández-Torquemada, Y.; González-Correa, J.M. Evaluation of the viability of Posidonia oceanica transplants associated with a marina expansion. Bot. Mar. 2009, 52, 471-476. [CrossRef]

236. Descamp, P.; Cornu, T.; Bougerol, M.; Boissery, P.; Ferlat, C.; Delaruelle, G.; Deter, J.; Gobert, S. Experimental transplantation of Posidonia oceanica. In Proceedings of the Thirteenth International Conference on the Mediterranean Coastal EnvironmentMEDCOAST 2017, Melliha, Malta, 31 October-5 November 2017; Ozhan, E., Ed.; MEDCOAST Mediterranean Coastal Foundation: Mugla, Turkey, 2017; Volume 1, pp. 427-435.

237. Gouvernement Princier. Projet D'extension en Mer: $500 \mathrm{~m}^{2}$ de Posidonies Transplantés. 2020. Available online: http:/ / www.gouv. mc/Action-Gouvernementale/L-Environnement/ Actualites/Projet-d-extension-en-mer-500-m2-de-posidonies-transplantes (accessed on 14 December 2020).

238. Paling, E.I.; van Keulen, M.; Wheeler, K.; Phillips, J.; Dyhrberg, R.; Lord, D.A. Improving mechanical seagrass transplantation. Ecol. Eng. 2001, 18, 107-113. [CrossRef]

239. Lewis, R.R.; Phillips, R.C. Experimental seagrass mitigation in the Florida Keys. In Proceedings of the Seventh Annual Conference on the Restoration and Creation of Wetlands, Tampa, FL, USA, 16-17 May 1980; pp. 155-173.

240. Kawasaki, Y.; Iituka, T.; Goto, H.; Terawaki, T.; Watanabe, Y.; Kikuti, K. Study on the technique for Zostera bed creation. CRIEPI Annu. Res. Rep. U 1988, 14, 231.

241. Zarranz, M.E.; González-Henríquez, N.; García-Jiménez, P.; Robaina, R.R. Restoration of Cymodocea nodosa seagrass meadows through seed propagation: Germination in vitro, seedling culture and field transplant. Bot. Mar. 2010, 53, 173-181. [CrossRef]

242. Bedini, R.; Nanneli, A.; Batistini, F. Restoration of Posidonia oceanica (L.) Delile meadows: Is there an effective methodology? J. Life Sci. 2013, 7, 722-726.

243. Meinesz, A.; Caye, G.; Loquès, F.; Molenaar, H. Polymorphism and development of Posidonia oceanica transplanted from different parts of the Mediterranean into the National Park of Port-Cros. Bot. Mar. 1993, 36, 209-216. [CrossRef] 
244. Terrados, J.; Marín, A.; Celdrán, D. Use of Posidonia oceanica seedlings from beach-cast fruits for seagrass planting. Bot. Mar. 2013, 56, 185-195. [CrossRef]

245. Orth, R.J.; Lefcheck, J.S.; McGlathery, K.S.; Aoki, L.; Luckenbach, M.W.; Moore, K.A.; Oreska, M.P.J.; Snyder, R.; Wilcox, D.J.; Lusk, B. Restoration of seagrass habitats leads to rapid recovery of coastal ecosystem services. Sci. Adv. 2020, 6, eabc6434. [CrossRef] [PubMed]

246. Boudouresque, C.F. Insights into the diversity of the biodiversity concept. Sci. Rep. Port-Cros Natl. Park 2014, $28,65-86$.

247. Faith, D.P. Conservation evaluation and phylogenetic diversity. Biol. Conserv. 1992, 61, 1-10. [CrossRef]

248. Sala, E.; Knowlton, N. Global marine biodiversity trends. Annu. Rev. Environ. Resour. 2006, 31, 93-122. [CrossRef]

249. Gray, J.S. The measurement of marine species diversity, with an application to the benthic fauna of the Norwegian continental shelf. J. Exp. Mar. Biol. Ecol. 2000, 250, 23-49. [CrossRef]

250. Warwick, R.M. Scaling of marine biodiversity. Océanis 1998, 24, 51-59.

251. Ellingsen, K.E. Biodiversity of a continental shelf soft-sediment macrobenthos community. Mar. Ecol. Prog. Ser. 2001, $218,1-15$. [CrossRef]

252. Willis, K.J.; Whittaker, R.J. Species diversity-Scale matters. Science 2002, 295, 1245-1248. [CrossRef]

253. García-Rubies, A.; Macpherson, E. Substrate use and temporal pattern of recruitment in juvenile fishes of the Mediterranean littoral. Mar. Biol. 1995, 124, 35-42. [CrossRef]

254. Cheminée, A.; Sala, E.; Pastor, J.; Bodilis, P.; Thiriet, P.; Mangialajo, L.; Cottalorda, J.M.; Francour, P. Nursery value of Cystoseira forests for Mediterranean rocky reef fishes. J. Exp. Mar. Biol. Ecol. 2013, 442, 70-79. [CrossRef]

255. Cheminée, A.; Pastor, J.; Bianchimani, O.; Thiriet, P.; Sala, E.; Cottalorda, J.M.; Dominici, J.M.; Lejeune, P.; Francour, P. Juvenile fish assemblages in temperate rocky reefs are shaped by the presence of macro-algae canopy and its three-dimensional structure. Sci. Rep. 2017, 7, 1-13. [CrossRef]

256. Morancy Conseil Environnement. Restauration des Herbiers de Zostera Dans L'étang de Berre par des Réimplantations Expérimentales de Zostera noltii \& Z. marina. Suivi des Transplantations à 3 ans; Morancy Conseil Environnement: Marseille, France, $2012 ;$ p. 32.

257. Pasqualini, V.; Pergent-Martini, C.; Clabaut, P.; Pergent, G. Mapping of Posidonia oceanica using aerial photographs and side scan sonar: Application off the Island of Corsica (France). Estuar. Coast. Shelf Sci. 1998, 47, 359-367. [CrossRef]

258. Bellissimo, G.; Sirchia, B.; Ruvolo, V. Monitoring of Posidonia oceanica meadows in the Sicilian coasts under the Water Framefork Directive (WFD). In Monitoring of Mediterranean Coastal Areas. Problems and Measurement Techniques; Bonora, L., Carboni, D., de Vicenzi, M., Eds.; Firenze University Press: Florence, Italy, 2020; pp. 510-518.

259. Morhange, C.; Laborel, J.; Hesnard, A.; Prone, A. Variation of relative mean sea level during the last 4000 years on the northern shores of Lacydon, the ancient harbour of Marseilles (chantier J. Verne). J. Coast. Res. 1996, 12, 841-849.

260. Pauly, D. Anecdotes and the shifting baseline syndrome of fisheries. Trends Ecol. Evol. 1995, 10, 430. [CrossRef]

261. Sáenz-Arroyo, A.; Roberts, C.M.; Torre, J.; Cariño-Olvera, M.; Enríquez-Andrade, R.R. Rapidly shifting environmental baselines among fishers of the Gulf of California. Proc. R. Soc. B Biol. Sci. 2005, 272, 1957-1962. [CrossRef]

262. Lotze, H.K.; Worm, B. Historical baselines for large marine animals. Trends Ecol. Evol. 2008, 24, 254-262. [CrossRef]

263. Navarro, L.; Ballesteros, E.; Linares, C.; Hereu, B. Spatial and temporal variability of deep-water algal assemblages in the Northwesten Mediterranean: The effects of an exceptional storm. Estuar. Coast. Shelf Sci. 2011, 95, 52-58. [CrossRef]

264. Coma, R.; Serrano, E.; Linares, E.; Zabala, M.; Ribes, M. Effect of a severe storm event on the mortality rate of the gorgonian Paramuricea clavata on the Medes Islands Marine Reserve and the nearby Montgrí coast. In Assessment of the Ecological Impact of the Extreme Storm of Sant Esteve's Day (26 December 2008) on the Littoral Ecosystems of the North Mediterranean, Spanish Coasts; Final Report (PIEC 200430E599); Centro de Estudios Avanzados de Blanes, Consejo Superior de Investigaciones Científica: Blanes, Spain, 2012; pp. 69-77.

265. Hereu, B.; Garcia-Rubies, A.; Linares, C.; Navarro, L.; Teixidó, N.; Garrabou, J.; Cebrian, E. Impact of Sant Esteve's storm (2008) in Paracentrotus lividus populations. In Assessment of the Ecological Impact of the Extreme Storm of Sant Esteve's Day (26 December 2008) on the Littoral Ecosystems of the North Mediterranean, Spanish Coasts; Final Report (PIEC 200430E599); Centro de Estudios Avanzados de Blanes, Consejo Superior de Investigaciones Científicas: Blanes, Spain, 2012; pp. 57-66.

266. Teixidó, N.; Casas, E.; Cebrián, E.; Linares, C.; Garrabou, J. Impacts on coralligenous outcrop biodiversity of a dramatic coastal storm. PLoS ONE 2013, 8, e53742. [CrossRef]

267. Gera, A.; Pagès, J.F.; Arthur, R.; Farina, S.; Roca, G.; Romero, J.; Alcoverro, T. The effect of a centenary storm on the long-lived seagrass Posidonia oceanica. Limnol. Oceanogr. 2014, 59, 1910-1918. [CrossRef]

268. Oprandi, A.; Mucerino, L.; de Leo, F.; Bianchi, C.N.; Morri, C.; Azzola, A.; Benelli, F.; Besio, G.; Ferrari, M.; Montefalcone, M. Effects of a severe storm on seagrass meadows. Sci. Total Environ. 2020, 748, 1-13. [CrossRef] [PubMed]

269. Boudouresque, C.F.; Astruch, P.; Bănaru, D.; Blanfuné, A.; Carlotti, F.; Faget, D.; Goujard, A.; Harmelin-Vivien, M.; Le Diréach, L.; Pagano, M.; et al. Global change and the management of Mediterranean coastal habitats: A plea for a socio-ecosystem-based approach. In Evolution of Marine Coastal Ecosystems under the Pressure of Global Change-Proceedings of Coast Bordeaux Symposium and of the 17th French-Japanese Oceanography Symposium; Ceccaldi, J.H., Hénocque, Y., Komatsu, T., Prouzet, P., Sautour, B., Yoshida, J., Eds.; Springer Nature: Basel, Switzerland, 2020; pp. 297-320.

270. Lepoint, G.; Vangeluwe, D.; Eisinger, M.; Paster, M.; van Treeck, P.; Bouquegneau, J.M.; Gobert, S. Nitrogen dynamics in Posidonia oceanica cuttings: Implications for transplantation experiments. Mar. Pollut. Bull. 2004, 48, 465-470. [CrossRef] [PubMed] 
271. Calvo, S.; Scannavino, A.; Luzzu, F.; Di Maida, G.; Pirrotta, M.; Orestano, C.; Paredes, F.; Montagnino, F.M.; Tomasello, A. Tecnica di reimpianto mediante supporto biodegradabile. In Conservazione e Gestione Della Naturalità Negli Ecosistemi Marino-costieri. Il Trapianto Delle Praterie di Posidonia oceanica; Manuali e Linee Guida n. 106/2014; Bacci, T., La Porta, B., Maggi, C., Nonnis, O., Paganelli, D., Rende, S.F., Polifrone, M., Eds.; ISPRA: Rome, Italy, 2014; pp. 47-51.

272. Scheffer, H. Posidonies. SM2 veut replanter les prairies méditerranéennes. Le Marin 2012, 3413, 20.

273. Calvo, S.; Scannavino, A.; Luzzu, F.; Di Maida, G.; Pirrotta, M.; Orestano, C.; Tomasello, A. Recupero di fondali a matte morta nel Golfo di Palermo mediante riforestazione con Posidonia oceanica. In Conservazione e Gestione Della Naturalità Negli Ecosistemi Marino-Costieri. Il Trapianto Delle Praterie di Posidonia oceanica; Manuali e Linee Guida n. 106/2014; Bacci, T., La Porta, B., Maggi, C., Nonnis, O., Paganelli, D., Rende, S.F., Polifrone, M., Eds.; ISPRA: Rome, Italy, 2014; pp. 43-46.

274. Jahnke, M.; Serra, L.A.; Bernard, G.; Procaccini, G. The importance of genetic make-up for restoration success-A case study of the seagrass Zostera noltii Hornem in a Mediterranean lagoon. In Proceedings of the 5th Mediterranean Symposium on Marine Vegetation, Portorož, Slovenia, 27-28 October 2014; Langar, H., Bouafif, C., Ouerghi, A., Eds.; RAC/SPA: Tunis, Tunisia, 2014; pp. 108-113.

275. Pergent, G. La protection légale de la Posidonie en France: Un outil efficace. Nécessité de son extension à d'autres pays méditerranéens. In Les Espèces Marines à Protéger en Méditerranée; Boudouresque, C.F., Avon, M., Gravez, V., Eds.; GIS Posidonie: Marseille, France, 1991; pp. 29-33.

276. Boudouresque, C.F.; Bianchi, C.N. Une idée neuve: La protection des espèces marines. In GIS Posidonie: Plus de 30 Ans au Service de La Protection et de La Gestion du Milieu Marin; Le Diréach, L., Boudouresque, C.F., Eds.; GIS Posidonie: Marseille, France, 2013; pp. 85-91.

277. Campbell, M.L. A decision-based framework to increase seagrass transplantation success. Biol. Mar. Mediterr. 2007, 10, 336-340.

278. den Hartog, C. Procedures for the restoration of seagrass beds. Biol. Mar. Mediterr. 2000, 7, 353-356.

279. Orth, R.J. Protection and restoration of seagrasses: Addressing global concerns from a local perspective in Chesapeake Bay, USA. Biol. Mar. Mediterr. 2000, 7, 401-404.

280. Jacob, C.; Buffard, A.; Pioch, S.; Thorin, S. Marine ecosystem restoration and biodiversity offset. Ecol. Eng. 2018, 120, 585-594. [CrossRef]

281. Bayraktarov, E.; Saunders, M.I.; Abdullah, S.; Mills, M.; Beher, J.; Possingham, H.P.; Mumby, P.J.; Lovelock, C.E. The cost and feasibility of marine coastal restoration. Ecol. Appl. 2016, 26, 1055-1074. [CrossRef]

282. Fonseca, M.S.; Kenworthy, W.J.; Thayer, G.W. Draft Guidelines for Mitigation and Restoration of Seagrasses in the United States and Adjacent Waters; NOAA Coastal Ocean Program Decision Analysis Series; National Fisheries Service: Silver Spring, MD, USA, 1996; p. 222.

283. Fonseca, M.S.; Kenworthy, W.J.; Thayer, G.W. Guidelines for Conservation and Restoration of Sea Grasses in the United States and Adjacent Waters; National Oceanic and Atmospheric Administration: Silver Spring, MD, USA, 1998; Volume 12.

284. Calumpong, H.P.; Fonseca, M.S. Seagrass transplantation and other seagrass restoration methods. In Global Seagrass Research Method; Short, F.T., Coles, R.G., Eds.; Elsevier Science: Amsterdam, The Netherlands, 2001; pp. 425-443.

285. Genot, I.; Caye, G.; Meinesz, A.; Orlandini, M. Role of chlorophyll and carbohydrate contents in survival of Posidonia oceanica cuttings transplanted to different depths. Mar. Biol. 1994, 119, 23-29. [CrossRef]

286. Meinesz, A.; Molenaar, H.; Bellone, E.; Loquès, F. Vegetative reproduction in Posidonia oceanica. II. Effects of rhizome length and transplantation season in orthotropic shoots. Mar. Ecol. 1992, 13, 163-174. [CrossRef]

287. Sinclair, E.A.; Verduin, J.; Krauss, S.L.; Hardinge, J.; Anthony, J.; Kendrick, G.A. A genetic assessment of a successful seagrass meadow (Posidonia australis) restoration trial. Ecol. Manag. Restor. 2013, 14, 68-71. [CrossRef]

288. Lafratta, A.; Serrano, O.; Masqué, P.; Mateo, M.A.; Fernandes, M.; Gaylard, S.; Lavery, S. Challenges to select suitable habitats and demonstrate 'additionality' in Blue Carbon projects: A seagrass case study. Ocean Coast. Manag. 2020, 197, 1-8. [CrossRef]

289. Orth, R.J.; McGlathery, K.J. Eelgrass recovery in the coastal bays of Virginia Coast Reserve. Mar. Ecol. Prog. Ser. 2012, 448, 173-176. [CrossRef]

290. Rezek, R.J.; Furman, B.T.; Jung, R.P.; Hall, M.A.; Bell, S.S. Long-term performance of seagrass restoration projects in Florida, USA. Sci. Rep. 2019, 9, 1-11. [CrossRef]

291. Matheson, F.E.; Reed, J.; dos Santos, V.M.; Mackay, G.; Cummings, V.J. Seagrass rehabilitation: Successful transplants and evaluation of methods at different spatial scales. N. Z. J. Mar. Freshw. Res. 2017, 51, 96-109. [CrossRef]

292. Leakey, R.; Lewin, R. The Sixth Extinction. Patterns of Life and the Future of Humankind; Doubleday: New York, NY, USA, 1995; p. 271.

293. Schnitzler, A.; Génot, J.C.; Wintz, M. Espaces protégés: De la gestion conservatoire vers la non-intervention. Courrier de l'Environnement de l'INRA 2008, 56, 29-44. 